\title{
Hydrodynamics in Evaporate-Bearing Fine-Grained Successions Investigated through an Interdisciplinary Approach: A Test Study in Southern Italy-Hydrogeological Behaviour of Heterogeneous Low-Permeability Media
}

\author{
E. Petrella ${ }^{(D)},{ }^{1}$ A. Bucci, ${ }^{2}$ K. Ogata, ${ }^{3}$ A. Zanini $\left(\mathbb{D},{ }^{4}\right.$ G. Naclerio, ${ }^{2}$ A. Chelli, ${ }^{1}$ R. Francese, ${ }^{1}$ \\ T. Boschetti, ${ }^{1}$ D. Pittalis, ${ }^{1}$ and F. Celico ${ }^{1}$ \\ ${ }^{1}$ Department of Chemistry, Life Sciences and Environmental Sustainability, University of Parma, Parco Area delle Scienze 157/A, \\ 43124 Parma, Italy \\ ${ }^{2}$ Department of Biosciences and Territory, University of Molise, Contrada Fonte Lappone, 86090 Pesche, Italy \\ ${ }^{3}$ Faculty of Earth and Life Sciences, VU University Amsterdam, De Boelelaan 1085-1087, Amsterdam, Netherlands \\ ${ }^{4}$ Department of Engineering and Architecture, University of Parma, Parco Area delle Scienze, 181/A, 43124 Parma, Italy
}

Correspondence should be addressed to E. Petrella; emma.petrella@unipr.it

Received 27 November 2017; Revised 13 March 2018; Accepted 29 March 2018; Published 8 May 2018

Academic Editor: Francesco Italiano

Copyright (C) 2018 E. Petrella et al. This is an open access article distributed under the Creative Commons Attribution License, which permits unrestricted use, distribution, and reproduction in any medium, provided the original work is properly cited.

\begin{abstract}
Messinian evaporates are widely distributed in the Mediterranean Sea as outcropping sediments in small marginal basins and in marine cores. Progressive filling of subbasins led to the formation of complex aquifer systems in different regions where hypersaline and fresh water coexist and interact in different manner. It also generates a significant diversification of groundwater hydrochemical signature and different microbial communities. In the case study, the hydrogeology and hydrochemistry of the whole system are influenced by good hydraulic connection between the shallower pyroclastic horizon and the underlying evaporate-bearing finegrained Messinian succession. This is demonstrated by the merge of hydrogeological, chemical, isotopic, and microbiological data. No mixing with deep ascending waters has been observed. As shown by geophysical, hydraulic, and microbiological investigations, the hydraulic heterogeneity of the Messinian bedrock, mainly due to karstified evaporitic interstrata/lenses, causes the hydraulic head to significantly vary with depth. Somewhere, the head increases with the depth's increase and artesian flow conditions are locally observed. Moreover, the metagenomic investigations demonstrated the existence of a poor hydraulic connection within the evaporate-bearing fine-grained succession at metric and decametric scales, therefore leading to a patchwork of geochemical (and microbiological) subenvironments.
\end{abstract}

\section{Introduction}

During the Messinian stage, the Mediterranean region was affected by a pervasive "salinity crisis" that allowed the deposition of an enormous volume of evaporitic sediments $[1,2]$. This "crisis" was influenced by a complex combination of tectonic and glacioeustatic processes that progressively restricted and partly isolated the Mediterranean Sea from the Atlantic Ocean [3-6]. Progressive filling of subbasins, characterized by different evaporite-forming environments, led to the formation of complex aquifer systems in different regions (e.g., [7]).
In such settings, brackish and salt waters are often found, which were especially used for thermal purposes. In Irpinia area, several saline waters can be found, but only a few hydrogeological and geochemical studies have been carried out, usually based upon results of a single sampling campaign. For example, $\mathrm{CaSO}_{4}$-type acid $(\mathrm{pH} 2.0)$ waters flow at Mefite spring (electrical conductivity $5800 \mu \mathrm{S} \mathrm{cm}{ }^{-1}$ ), due to the interaction between groundwater and evaporites of Messinian age mainly made of gypsum [8]. In such a spring, significant content in $\mathrm{H}_{2} \mathrm{~S}, \mathrm{CO}_{2}$, and $\mathrm{CH}_{4}$ is probably due to the interaction with deep fluids, which locally rise along fault zones [9]. Conversely, NaCl-type hypersaline waters 
flow at Pozzo del Sale spring that was used as a sort of salt-pan until 1817 or for therapeutic purposes from 1894 to 1915. This spring was analyzed a few times in the past. Some physicochemical analyses were made during the early 20th Century (unpublished data), in the 1970s [10] and in July 1979 and February 1980 [9] showing significant changes in ion concentrations over time.

Worldwide, different hydrogeological behaviours have been detected for aquifers made of (partially or entirely) evaporitic sediments. For example, Acero et al. [11] found that the hydrogeology and hydrochemistry of the studied system are mainly influenced by the mixing of saline groundwater that interact with the evaporitic rocks and more diluted waters, flowing into an overlying porous aquifer. Similar results, from the hydrochemical point of view, were also obtained by Chiesi et al. [12] in Northern Italy, even though they observed a significant influence of surface waters infiltrating in swallow holes. In all these systems, the hydrogeology and hydrochemistry of the evaporitic aquifer are not influenced by deep ascending regional groundwater, opposite to observations made in other evaporitic systems in Spain and USA (e.g., [1315]).

In this study, an attempt for gaining deeper knowledge on the hydrogeological behaviour of evaporate-bearing finegrained systems has been carried out. Some hydraulic features, the hydrogeological regime, the major hydrochemical components, and stable isotopes as well as some microbial indicators of fecal contamination and microbial communities in a test site in southern Italy have been investigated. The interdisciplinary approach provides much more reliable quantitative information on the hydrodynamics in complex heterogeneus system than a single-disciplinary application. The test site has been studied in a more detailed way over the last decade. Firstly, the only hypersaline groundwater (Pozzo del Sale spring and a couple of wells drilled very close to the spring) was thoroughly investigated, by analyzing the variation of some hydrochemical and isotopic features over time. This first study allowed us to understand that hypersaline groundwater is characterized by mixing with fresh waters, and both are of meteoric origin [16]. A second investigation was carried out within a wider surrounding area, but always related to the only hydrochemical and isotopic features [17]. This study suggested that the water chemistry of the aquifer system may initially be regarded as a result of easy and common low temperature interactions between meteoric water and Late Messinian evaporites, which produce $\mathrm{Ca}$-bicarbonate and $\mathrm{Na}$-chloride when passing through Ca-sulfate waters. However, closer inspections revealed additional geochemical facies within the system, which can be further complicated by mineralogical heterogeneity within the aquifer system, the existence of different meteoric recharge areas, and the mixing of groundwater and allochthonous fluids as terrestrial mud volcanoes.

From the results of the interdisciplinary approach, a hydrogeological conceptual model has been established for the investigated system that can be potentially applied to other evaporitic karstified environments. In a wider context, the joint application of different methodologies could be useful for analyzing the hydrogeological functioning of other poorly studied aquifers. Moreover, the results of this research will also provide the basis for a proper management of groundwater in other contexts where saline/hypersaline waters cause quality deterioration of freshwater in surface and ground waters.

\section{Study Area}

The Pozzo del sale site is close to Grottolella town (Irpinia area, southern Italy), where upper Messinian terrigenous deposits crop out (Figure 1(a)). These deposits are well exposed only in the northern Irpinia/southern Daunia area [20-23] and in the southern Sannio/western Irpinia area $[24,25]$. Within the study area the stratigraphic sequence is made up by laterally heteropic and interfingering lenses of thin-bedded grey, red and green marly argillites, calcilutites, calcareous marls, carbon-rich fossil diatoms with sulphur concretions, clays, and marls with laminae of small gypsum crystals $[20,22]$. Halite was also found within the sequence [26]. The inferred depositional setting is lacustrine-lagoonal with high salinity variations from hypersaline to brackish to fresh waters, evolving upward into alluvial-deltaic environments ([27] and reference therein).

At the study site, the heterogeneous aquifer system is made of (from the top to the bottom) (i) pyroclastic deposits and (ii) Messinian bedrock [16].

The pyroclastic horizon is up to about 10 meters thick and characterized by a global homogeneity, testified by a narrow envelope of grain size curves with a prevailing clay loam texture. From the hydrogeological point of view, it represents the so-called "upper subsystem" (unconfined aquifer). Its hydraulic conductivity usually ranges between $3.2 \cdot 10^{-5}$ and $7.1 \cdot 10^{-6} \mathrm{~m} \mathrm{~s}^{-1}$.

The Messinian sediments are mainly grey and green argillites that locally lie below the pyroclastic deposits. Different minerals of evaporitic origin (halite $[\mathrm{NaCl}]$, gypsum $\left[\mathrm{CaSO}_{4} \cdot 2 \mathrm{H}_{2} \mathrm{O}\right]$, epsomite $\left[\mathrm{MgSO}_{4} \cdot 7 \mathrm{H}_{2} \mathrm{O}\right]$, and chloromagnesite $\left[\mathrm{MgCl}_{2}\right]$ ) were found within the argillites in boreholes drilled in the spring's area [10]. With regard to hydraulic properties of the aquifer (the so-called "lower subsystem"), a former pumping test yielded a transmissivity of $6.0 \cdot 10^{-5} \mathrm{~m}^{2} \mathrm{~s}^{-1}$ close to the former Pozzo del Sale spring (Figure 1(a) [16]). This relatively high value was explained assuming the existence of a network of interconnected fractures within clays and dissolution openings within the interbedded and laterally heteropic argillitic-evaporitic sediments [16]. The interaction of these subvertical and subhorizontal planar discontinuities may provide preferential groundwater flow pathways. In this framework, the overall structural architecture, which provides the hydraulically conductive fracture sets, appears dominated by NNE-SSW- to ENE-WSW-trending tectonic lineaments, with a major normal fault oriented WNW-ESE, downthrowing the northern block, passing few hundred meters to the SW of the study site. Notably, a NE-SW-striking fault, recognizable either on outcrop and landscape, roughly intercepts both spring's location and the tested well site (see pumping tests below), abutting against the main normal fault. Such structural discontinuities occur within the Messinian deposits, being sealed by the overlying pyroclastites [29]. The 


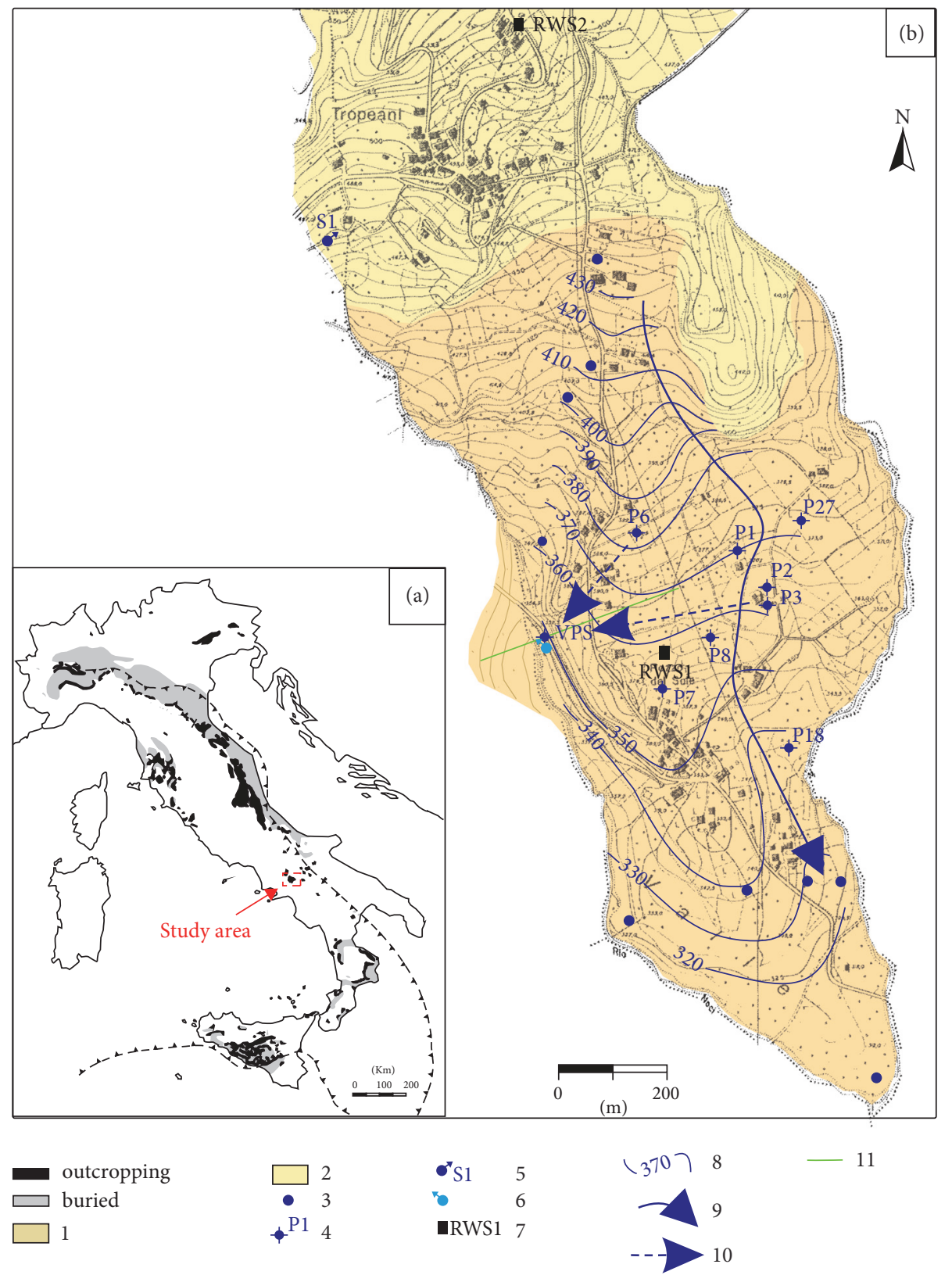

Figure 1: (a) Areal distribution of Messinian deposits (black: outcrops; grey: buried deposits) in Italy and location of the study area. (b) Hydrogeological map of the study area (piezometric contour lines related to February 2007). Legend: 1: pyroclastic deposits; 2: Messinian deposits; 3: borehole used to reconstruct the groundwater flow net; 4: monitoring borehole; 5: spring; 6: former Pozzo del Sale spring; 7: rainwater sampler; 8: potentiometric contour line related to the shallower groundwater (upper subsystem) (m asl); 9: main groundwater flow direction in the upper subsystem; 10: groundwater flow direction in the lower subsystem; 11: geophysical section.

lower subsystem lies below permeable pyroclastic deposits, therefore suggesting unconfined groundwater flow at catchment scale. However, its heterogeneity causes the hydraulic head to vary with depth. The variation of the hydraulic head with depth is testified by artesian flow from deeper wells (P6, in the case study), that locally intercepted higher conductive fractures/dissolution openings confined within very low permeable argillites (see more details hereafter). The artesian conditions are also due to the hydraulic link between the local bedrock and the outcropping Messinian deposits upgradient with reference to the study site (Figure 1).

The hypersaline Pozzo del Sale spring flowed until June 2005, before the drilling of the $1 \mathrm{~m}$ diameter borehole VPS (19 $\mathrm{m}$ deep and fully screened within the Messinian bedrock [lower subsystem]) a few meters upgradient, which induced the spring to stop flowing. During the hydrologic year 2004/2005 the spring's discharge ranged from 0.007 to $0.051 \mathrm{~s}^{-1}$. Both the spring and the well hydrographs 
TABLE 1: Main features of the observation wells.

\begin{tabular}{lcccc}
\hline ID & $\begin{array}{c}\text { Altitude } \\
(\mathrm{m} \text { asl })\end{array}$ & $\begin{array}{c}\text { Depth } \\
(\mathrm{m})\end{array}$ & $\begin{array}{c}\text { Screening } \\
\text { (m from the ground) }\end{array}$ & $\begin{array}{c}\text { Investigated } \\
\text { subsystem }\end{array}$ \\
\hline P1 & 372 & 3 & $1-3$ & Upper \\
P2 & 367 & 27 & $20-27$ & Lower \\
P3 & 367 & 26 & $21-26$ & Lower \\
P6 & 388 & 27 & $20-27$ & Lower \\
P7 & 359 & 21 & $19-21$ & Lower \\
P8 & 363 & 6 & $1-6$ & Upper \\
P18 & 339 & 10 & $1-10$ & Upper \\
P27 & 377 & 4 & $1-4$ & Upper \\
VPS & 349 & 1.5 & $0.5-1.5$ & Lower \\
\hline
\end{tabular}

suggested relatively fast influence of precipitation events on groundwater regime [16].

\section{Methodology}

3.1. Hydrogeological and Geophysical Investigations. The groundwater head was measured in 19 wells on February 6,2007 , to reconstruct the groundwater flow net within the study area (Figure 1(b)). The hydraulic head was measured on a biweekly basis from March 2007 to February 2008 in 7 out of 19 wells (P1, P2, P3, P7, P8, P18, and P27). From January 2008, the hydraulic head was measured on the same basis in a new well (VPS) that was drilled close to the former hypersaline Pozzo del Sale spring. These measurements were carried out with a water level meter.

Wells P1, P8, P18, and P27 are drilled within the pyroclastic deposits (upper subsystem), while the deeper wells (P2, P3, P7, and P6) are drilled within the pyroclastic horizon and the underlying Messinian bedrock (lower subsystem) (Table 1). These deeper wells were screened only in the bedrock. In well P6, the groundwater flows out under natural pressure.

Two pumping tests were carried out in wells P3 and P7. The hydraulic heads have been monitored continuously in pumping as well as in monitoring wells.

Precipitations were monitored on an hourly basis at a meteorological station located within the study area.

Resistivity data were collected in an area of $350 \mathrm{~m}$ by $400 \mathrm{~m}$ around the VPS well (Figure 1) using a commercial georestivimeter, to investigate the existence of discontinuous hypersaline bodies within the Messinian sequence. Terrain morphology and dense vegetation affected the geometry of the field layout that became fairly irregular. About 200 measurements were taken locating 250 current and potential electrodes along various spreads mostly elongated in northsouth and east-west directions. The measurements were then inverted to a true resistivity volume using a finite elements approach on a tetrahedral grid. Inversion was fully $3 \mathrm{D}$ and topography was also modelled to account for electrical field distortion due to high morphology gradients. This inversion algorithm is well described in the literature (e.g., [30]) and it is generally indicated as the smoothness-constrained approach under Occam assumptions. The misfit between measured and calculated values was lower than $5 \%$ for most of the collected data-points.

3.2. Sampling and Analyses. The sampling campaigns were carried out from March/May 2007 to April 2008.

Rainwater samples for $\delta^{18} \mathrm{O}$ and $\delta^{2} \mathrm{H}$ analyses were collected on a monthly basis in two rain samplers, RWS1 and RWS2, located within the aquifer system, respectively (Figure 1(b)), at 365 and 525 meters above sea level (m asl).

The rain precipitated during the whole December 2007 (early recharge 2007/2008) was collected in order to perform ${ }^{3} \mathrm{H}$ analyses. The rain sampler is located close to RWS2.

The rainfall was collected using ten-liter polyethylene bottles containing about $300 \mathrm{ml}$ of Vaseline oil to prevent evaporation processes. Oil contamination was carefully avoided by syringing the water samples out of the bottle.

Groundwater samples for chemical, stable isotope $\left(\delta^{18} \mathrm{O}\right.$, $\left.\delta^{2} \mathrm{H}\right)$ and microbiological analyses were collected on a monthly basis. The sampling was carried out at spring S1 (for microbiological analyses only on March, May, and November 2007), and at the bottom of P1, P2, P3, P6, P7, P8, P18, and P27 wells. The well VPS was purposely drilled close to the hypersaline Pozzo del Sale spring, which dried out in June 2005. Thus, from January 2008 onwards, chemical, isotopic $\left(\delta^{18} \mathrm{O}, \delta^{2} \mathrm{H}\right)$, and microbiological analyses were made also on groundwater samples collected in VPS, at the well bottom.

Groundwater samples (1.5 liters each) were collected once in sterile bottles for biomolecular analyses at the well bottom in each of wells P1, P2, P3, P6, P7, P8, P18, P27, and VPS, and at spring $\mathrm{S} 1$. Water samples were transported in a refrigerated box to the laboratory.

Groundwater samples for ${ }^{3} \mathrm{H}$ analyses were collected once in wells P6, P7, P18, and VPS, at the well base.

To collect groundwater, a discrete groundwater sampler was used (Solinst, mod 425).

$\mathrm{pH}$ measurements were performed in the laboratory with a $\mathrm{pH}$ electrode and the EC with a WTW laboratory conductometer. Bicarbonate was determined by titration with $\mathrm{HCl}$. Major ions concentrations were determined by ion chromatography using a DIONEX ICS-1000 model connected to a DIONEX AS40 Automated Sampler. For cation preservation samples were acidified at $\mathrm{pH}<3$ with concentrated $\mathrm{HNO}_{3}$ solution. The accuracy of the analyses was checked by the ionic balance. As per spring and groundwater, analyses with an ionic balance of $\pm 5 \%$ were considered acceptable.

Stable isotope analyses $\left(\delta^{18} \mathrm{O}, \delta^{2} \mathrm{H}\right)$ were carried out at the Isotope Geochemistry Laboratory, of the University of Parma, Italy, while ${ }^{3} \mathrm{H}$ content was analysed at the Institute of Geosciences and Earth Resources (CNR), Pisa, Italy. The analytical precision was $\pm 0.1 \%$ for $\delta^{18} \mathrm{O}, \pm 1 \%$ for $\delta^{2} \mathrm{H}$. The compositions of $\delta^{18} \mathrm{O}$ and $\delta^{2} \mathrm{H}$ are reported in $\delta \%$ o versus V-SMOW standard (Vienna Standard Mean Ocean Water). Taking into consideration the known altitude effect [31], $\delta^{18} \mathrm{O}$ was used as environmental tracer [32-34] to identify the mean elevation of the recharge areas of spring and groundwater. The performance of tritium analyses was increased by electrolytic enrichment. 
Water samples for microbiological analyses were collected in sterile $1000 \mathrm{ml}$ bottles and transported in a refrigerated box to the laboratory. Filtration processes were made within $2 \mathrm{~h}$ after sampling. Indicators of microbial contamination were determined using classic methods of water filtration on sterile membrane filters (pore size $0.45 \mu \mathrm{m}$ ) with incubation on (a) m-FC agar for $24 \mathrm{~h}$ at $44^{\circ} \mathrm{C}$ for fecal coliforms and (b) Slanetz-Bartley agar (SB) for $4 \mathrm{~h}$ at $37^{\circ} \mathrm{C}$ and $44 \mathrm{~h}$ at $44^{\circ} \mathrm{C}$ for fecal enterococci.

In such a study, fecal bacteria have been used as tracers of rapid interaction between older saline groundwater and fresh infiltration water, the latest interacting [16] with local sources of fecal matter on the ground. In fact, die off kinetics for fecal coliforms and fecal enterococci in groundwater were determined and, on average, have respective decay rates of 4.2 and 11.6 days for a $90 \%$ reduction [35-38]. For a $99 \%$ reduction, fecal coliforms have a decay rate of several tens of days [39].

To carry out molecular biological analyses, water samples $(1.5 \mathrm{~L})$ were filtered through mixed esters of cellulose filters $\left(\mathrm{S}-\mathrm{Pak}^{\mathrm{TM}}\right.$ Membrane Filters, $47 \mathrm{~mm}$ diameter, $0.22 \mu \mathrm{m}$ pore size, Millipore Corporation, Billerica, MA, USA) within $8 \mathrm{~h}$ of collection. Just after filtration, filters were stored at $-80^{\circ} \mathrm{C}$ until nucleic acid extraction. Nucleic acid extraction was carried out by the method described in Gich et al. [40]. The $\mathrm{V} 3$ region of $16 \mathrm{~S}$ rDNA genes from the bacterial communities was amplified by Polymerase Chain Reaction (PCR) with the primer set PRBA338f (5'ACTCCTACGGGAGGCAGCAG; [41]) and PRUN518r (5'ATTACCGCGGCTGCTGG [42]). The GC clamp described by Muyzer et al. [42] was included on the $5^{\prime}$ end of the forward primer. Denaturing Gradient Gel Electrophoresis (DGGE) was performed with the BIO-RAD DCode $^{\mathrm{TM}}$ Universal Mutation Detection System. A cluster analysis of the DGGE patterns was conducted using FPQuest Software Version 5.1 (BIO-RAD Laboratories, Inc., Hercules, CA, USA). The similarity in the profiles was calculated based on the Dice coefficient with the UPGMA clustering algorithm.

\section{Results}

4.1. Hydrogeological Settings. Well hydrographs suggest nonsynchronous fluctuations of groundwater head within the whole heterogeneous aquifer system (Figure 2).

The hydraulic heads in shallower wells (P1, P8, P18, and P27 drilled within the upper subsystem) are well correlated to each other, with the exclusion of well P1. The good correlation is in agreement with (i) the overall homogeneity of the pyroclastic horizon and (ii) the nearly constant thickness of the unsaturated zone, both making the infiltration waters reach the groundwater surface almost synchronously.

Differently, the hydraulic heads in deeper wells (P2, P3, and P7 which are screened within the lower subsystem) are poorly correlated to each other, even where the wells are very close to each other (e.g., P2 and P3, $21 \mathrm{~m}$ apart). The poor correlation within the lower subsystem is in agreement with the great heterogeneity of the bedrock, where low-permeability argillites coexist with higher permeability fractures and dissolution openings.
When analyzing the results of the pumping tests in P3 and P7, a transmissivity in the order of $10^{-5} \mathrm{~m}^{2} \mathrm{~s}^{-1}$ is calculated, very close to that obtained by Celico et al. [16], close to well VPS.

Within the upper subsystem, the groundwater surface slopes southwards with a hydraulic gradient ranging from $5 \%$ to $10 \%$ (Figure 1(b)), in agreement with the topographic slope. Within the bedrock (lower subsystem), the groundwater flows mainly westwards (Figure 1(b)), towards the only hypersaline spring (the former Pozzo del Sale). However, the few deeper wells available at the study site do not allow reconstructing the potentiometric surface.

A resistivity profile was extracted from the $3 \mathrm{D}$ resistivity volume along the section with higher sensitivity and data are interpretable down to a depth of about $80 \mathrm{~m}$ below the surface. Resolution, according to electrode coverage, is maximum in the distance segment comprised between $50 \mathrm{~m}$ and $350 \mathrm{~m}$. Subsurface settings appear to be quite complicated as resistivity $(\rho)$ ranges from $5 \Omega * \mathrm{~m}$ to values higher than $50 \Omega * \mathrm{~m}$ (Figure 3 ) exhibiting also an irregular distribution. The most prominent feature is a low resistivity body (with $\rho$ lower than $5 \Omega * \mathrm{~m}$ ) located eastwards of Rio Noci and surrounded by terrains exhibiting resistivity up to $40 \Omega * \mathrm{~m}$ and overtopped by a near surface layer with resistivity of approximately $20-25 \Omega * \mathrm{~m}$. At larger depths resistivity values increase again to values of about $50-70 \Omega * \mathrm{~m}$. The maximum thickness of the conductive body is roughly $40 \mathrm{~m}$, while the overtopping resistive layer is $5-10 \mathrm{~m}$ thick.

The resistivity distribution in depth well shows the presence of two distinct aquifer subsystems. The upper subsystem is represented by the pyroclastic horizon (K2 in Figure 3). This unit exhibits an average resistivity of $30 \Omega * \mathrm{~m}$ with a thickness ranging from $5 \mathrm{~m}$ to $10 \mathrm{~m}$, in agreement with borehole data. The low resistivity values are related to the relative abundance of clay minerals. The second (lower) subsystem is hosted in the Messinian bedrock and shows a clear drop in the resistivity that lowers sown to values around $5 \Omega * \mathrm{~m}$ (K1 in Figure 3 ). Resistivity in this unit, because of the peculiar lithology, was expected to increase as visible at larger depths. The reason of the anomalous behaviour can be linked to dissolution of evaporitic intrastrata that caused the development of voids and cavities resulting in a secondary porosity. These voids are filled with highly conductive hypersaline waters lowering the overall resistivity values. Finally the conductive body seems to be laterally bounded by higher resistivity terrains suggesting a clusterization of the conductive bodies.

4.2. Physicochemical Investigations. Through the application of ternary classification diagrams, using major cations and anions and the calculated TDS, waters may be grouped in four categories (Figures 4(a) and 4(b)): (a) brine (well VPS, such as spring PS and another well investigated by Celico et al. [16]) and brackish NaCl-type (well P2, P7), (b) brackish $\mathrm{NaSO}_{4}$-type (well P3), (c) brackish $\mathrm{CaSO}_{4}$-type (well P6), and (d) freshwater $\mathrm{CaHCO}_{3}$-type (wells P1, P8, P18, and P27). The latter group shows shifts on the diagram, in particular for well P27 trending towards a $\mathrm{NaCl}$ composition passing the $\mathrm{NaSO}_{4}$ one, probably due to mixing. Mixing is showed also in the well 


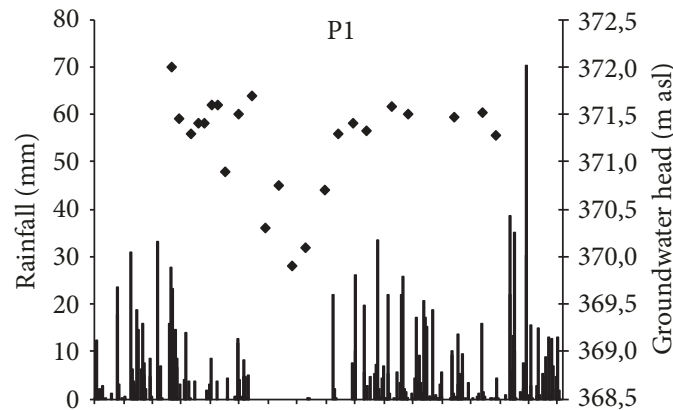

ㅇㅎㅇㅇㅎㅇㅇㅇㅇㅇㅇㅇㅇㅇㅇㅇㅇㅇㅇㅇㅇㅇㅇㅇㅇㅇㅇ

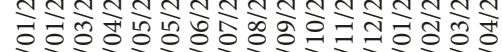

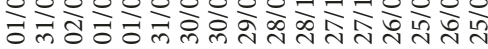

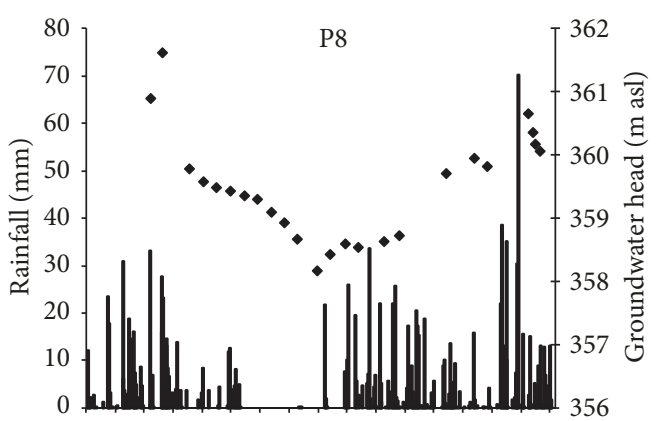

ㅇㅎㅇㅇㅇㅇㅇㅇㅇㅇㅇㅇㅇㅇㅇㅇㅇㅇㅇㅇㅇㅇㅇㅇㅇㅇㅇㅇ

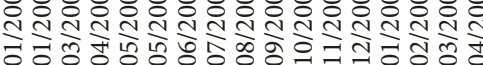

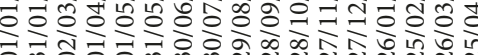
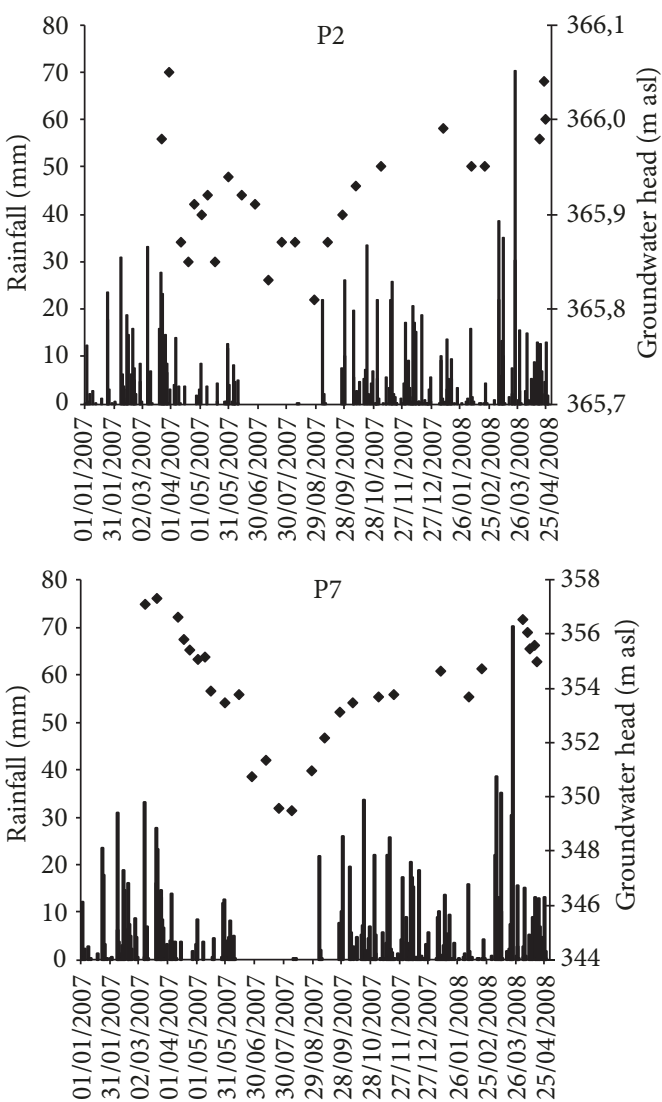

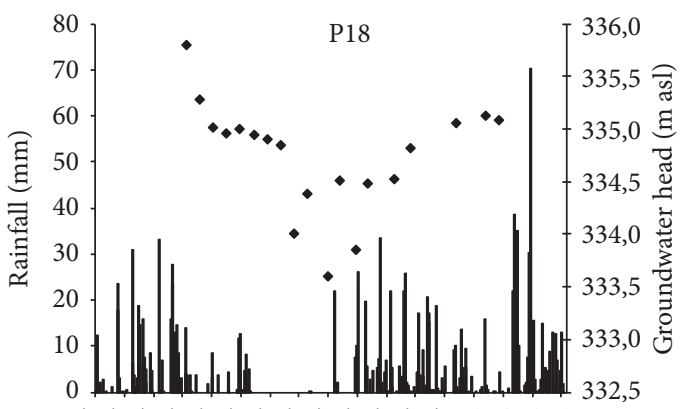

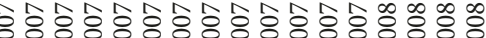

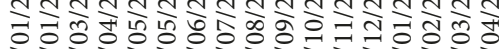
ómó ó

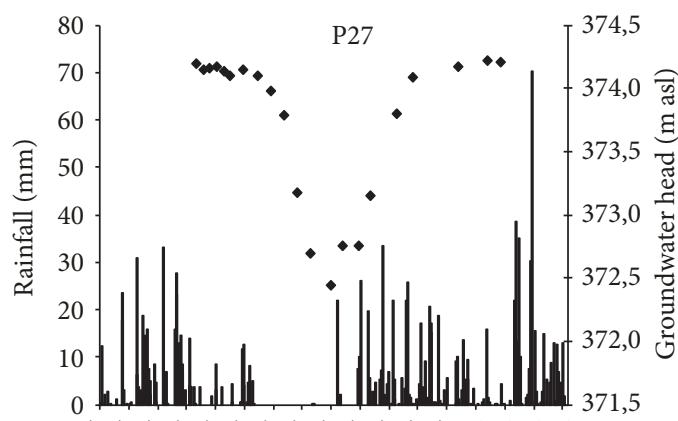

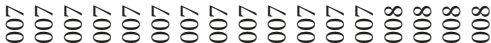

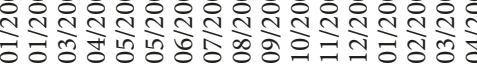

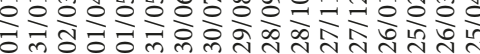

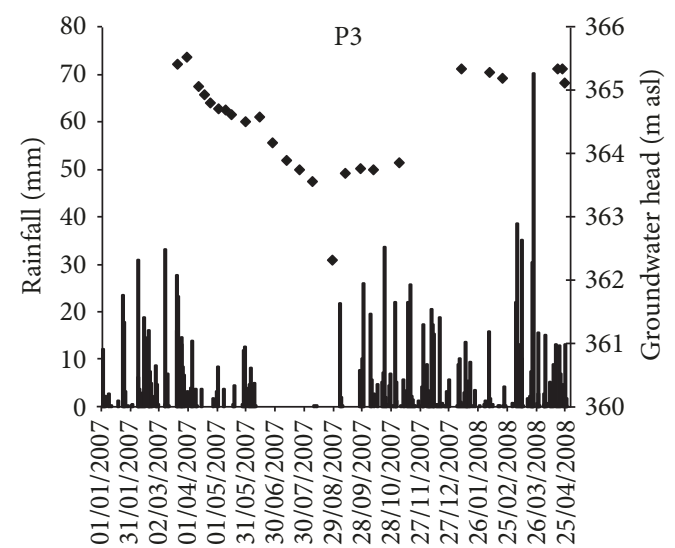

Figure 2: Groundwater head fluctuation in the shallower (P1, P8, P18, P27) and in the deeper wells (P2, P3, P7). The bars represent the daily rainfall. 


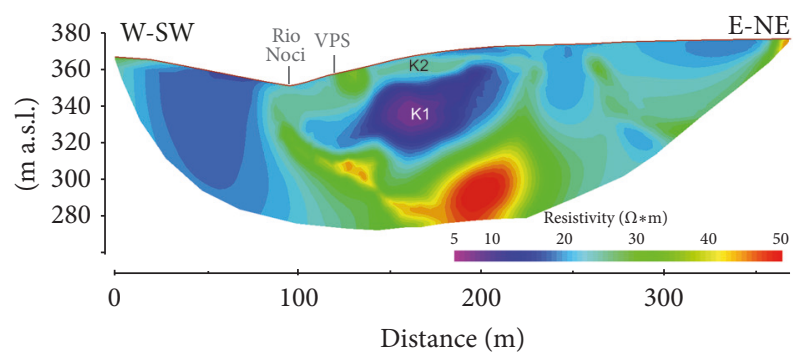

FIGURE 3: Resistivity profile showing a three-layer structure. The near surface medium resistivity unit is marked with letter K1, while the underlying very conductive body is marked with letter $\mathrm{K} 2$. In the deepest layer, resistivity raises up to values larger than $50 \Omega * \mathrm{~m}$.

P7 which trends to a lesser salinity but maintaining a $\mathrm{NaCl}$ composition.

On the whole, the other samples follow the well-known chemical evolution of an evaporate-dissolving groundwater [19] that is dissolution or equilibrium with limestone and gypsum (evolution from bicarbonate towards sulfate composition) and then halite dissolution (from sulfate to chloride composition).

In the brine plot (Figure 4(c)), all but well P7 occupy the neutral water field. VPS brine, bicarbonate, and sulfate samples are clustered near to calcite-gypsum line, in line with the evaporate-dissolving model. The shift towards the $\mathrm{SO}_{4}$ corner showed by other samples is due to the dissolution of more soluble sulfates as epsomite (P1) and $\mathrm{Na}_{2} \mathrm{SO}_{4}$-bearing salts (P2, P3).

This latter hypothesis is confirmed calculating the molar ratio between the sodium and sulfate excess $(\mathrm{NaCl}-$ $\left.\mathrm{HCO}_{3}\right) /\left(\mathrm{SO}_{4}-\mathrm{Ca}-\mathrm{Mg}\right)$. The mean ratio of 2 showed by $\mathrm{P} 2$ and $\mathrm{P} 3$ sample is in agreement with the $\mathrm{Na} / \mathrm{SO}_{4}$ ratio of 2 obtaining dissolving Na-sulfate salt. The well P6 shows the highest $\mathrm{Na} / \mathrm{Cl}$ ratio but a median sodium/sulfate excess ratio of 1.5. Modifying the ratio as $\left[\left(\mathrm{NaCl}-\mathrm{HCO}_{3}\right) /\left(\mathrm{SO}_{4}-\mathrm{Ca}-\mathrm{Mg}\right)\right]$ $+\mathrm{K}$, a ratio of 2 is obtained that may indicate the presence of a $\mathrm{Na}(\mathrm{K}) \mathrm{SO}_{4}$ salt.

4.3. Isotope Investigations. With regard to stable isotopes composition of local rainwater, plotting all the available monthly $\delta^{18} \mathrm{O}$ versus $\delta^{2} \mathrm{H}$ values, the following equation can be calculated:

$$
\delta^{2} \mathrm{H}=6.78 \delta^{18} \mathrm{O}+3.65 .
$$

This equation (LMWL) is not too far from the meteoric water line found by Longinelli and Selmo ([43]; SIMWL in Figure 5) in the whole southern Italy $\left(\delta^{2} \mathrm{H}=6.97 \delta^{18} \mathrm{O}+\right.$ 7.32). The authors suggested that both slope and deuteriumintercept value depart from the values of the Global Meteoric Water Line (GMWL; $\delta^{2} \mathrm{H}=8.14( \pm 0.02) \delta^{18} \mathrm{O}+10.9( \pm 0.2)$, $R=0.98$ [28]) due to the influence of Mediterranean basins surrounding southern Italy. Furthermore, the deuterium excess for both the stations is in the range (from 10.58 for RWS1 up to 12.13 for RWS2; the values are the average calculated in 1 year of monitoring; Table 2) of the moisture of air masses with Atlantic and Mediterranean proveniences.
The variation over the time of the isotopic content in RWS1 and RWS2 is analogous and the mean weight annual value of RWS1 is less depleted than RWS2, as expected. The seasonal effect is relevant: during the spring-summer period, heavier isotopic values were detected in both the rainwater samplers, as well as a variation of deuterium excess from 6.6 to 10.1. On the contrary, during the autumn-winter period, the isotopic content is lighter in both RWS1 and RWS2 and the variation of the deuterium excess is from 11.9 up to 15.5. This underlines the changing of the air mass origin during the seasons.

The results of isotopic analyses on rainwater samples were used to calculate the $\delta^{18} \mathrm{O}$ vertical gradient at the study site $(-0.22 \% 0 / 100 \mathrm{~m})$. This gradient is consistent with the overall mean value of the vertical isotopic gradient calculated throughout Italy (fairly close to $-0.20 \% / 100 \mathrm{~m}[43]$ ), and the gradient found at other sites in southern Italy $(-0.17 \% 0 / 100 \mathrm{~m}$ in [44]; $-0.16 \% / 100 \mathrm{~m}$ in [45]). It is also in the range of values observed throughout the world $(-0.15 \%$ o to $-0.50 \% / 100 \mathrm{~m}$ [34]). Such a gradient was then used to speculate about the mean elevation of the recharge areas of spring and groundwater (Table 3).

After plotting the isotopic data of both spring and groundwater in a $\delta^{18} \mathrm{O}$ versus $\delta^{2} \mathrm{H}$ scattergram (Figure 5), it is observed that the samples are well situated along the LMWL, therefore suggesting a complete meteoric origin of fresh, brackish, and hypersaline groundwater. This result is in agreement with suggestions of Celico et al. [16] who stated that there is no interaction between fossil/connate hydrocarbonbearing brines and deep basinal flow systems or geothermal systems at the study site. As a matter of fact, in these systems, the samples typically fall on the right side away from the meteoric water line. This is due to the water-rock interaction and/or evaporation of paleoseawater source [18, 34].

The isotopic composition of spring and groundwater samples did not significantly vary over time (Table 2 ; variations were lower than the $2 \sigma$ error of the $\delta^{18} \mathrm{O}$ and $\delta^{2} \mathrm{H}$ analyses), with the exception of VPS. Moreover, temporal variations were attenuated to less than $5 \%$ of that observed in the precipitation (Figure 6), according to the observations made in other aquifer types (e.g., [46-49]).

The calculation of the mean elevation of the recharge areas (Table 3) points out an apparent paradox, because the calculated elevations are always lower than those at which the spring S1 flows out and observation wells were drilled. This difference ranges between a minimum of $22 \mathrm{~m}$ and a maximum of $257 \mathrm{~m}$. This paradox can be explained assuming a significant interannual variation of the isotopic composition of rainwater at the study site, and the isotopic signature of groundwater to be influenced by rainwater older than that precipitated during the observation period. This hypothesis is in agreement with observations at the IAEA sampling station of Genova (Italy) where the mean annual amount-weighted $\delta^{18} \mathrm{O}$ in rainwater ranged between $-6.83 \%$ and $-3.06 \%$, from 1973 to 2000.

With regard to tritium, P6-water has a very low ${ }^{3} \mathrm{H}$ content $(0.9 \pm 0.4 \mathrm{TU})$ consistent with a long mean residence time of such brackish $\mathrm{CaNaSO}_{4}$-type water in the lowpermeability bedrock (lower subsystem). Both P7-water and 


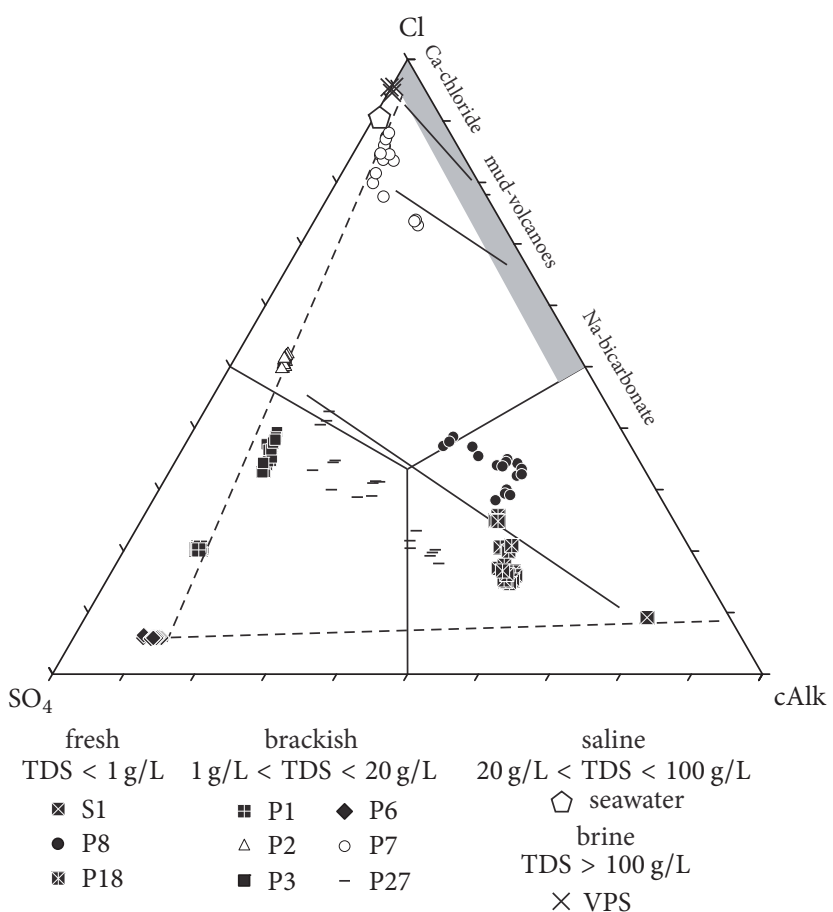

(a)

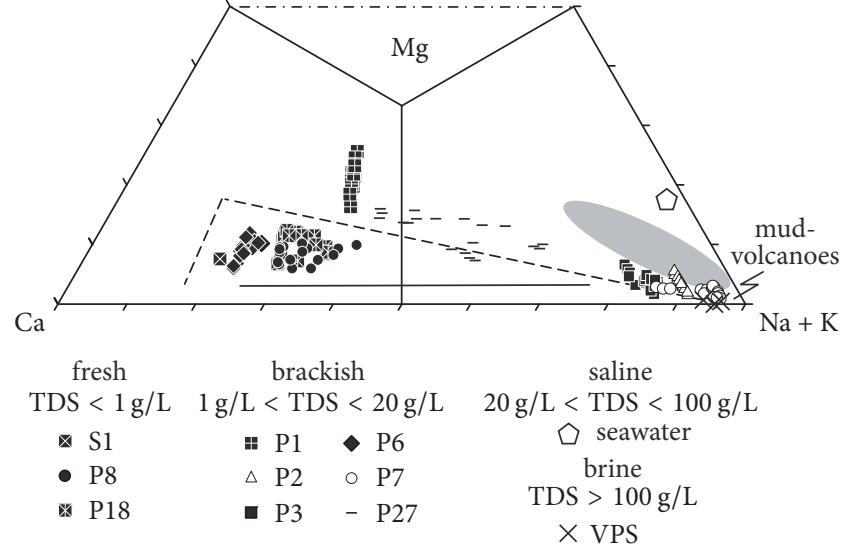

(b)

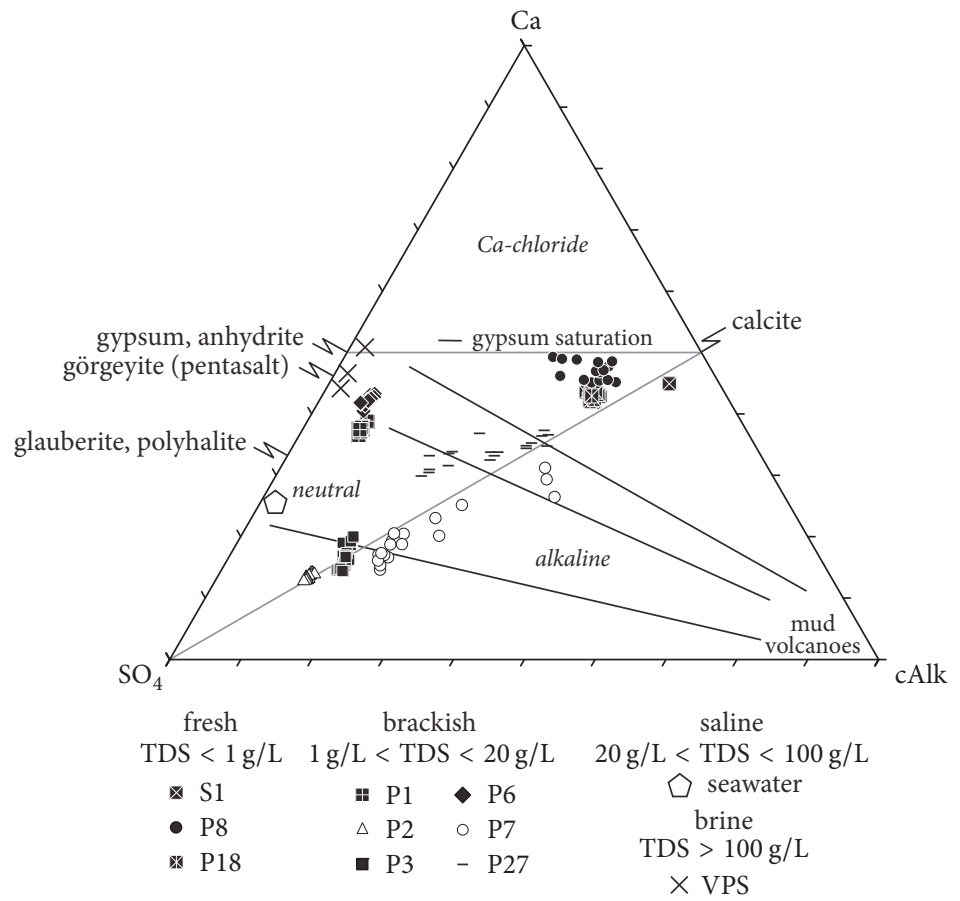

(c)

Figure 4: Major ions classification ((a) and (b)) and brine (c) ternary diagrams of the borehole and spring waters sampled at Pozzo del Sale (modified after [17]). In (a) and (b), grey area shows the compositional range of the Messinian Ca-chloride formational fluids from the Northern Apennines (Ca ternary subdiagram in (c) [18]), whereas dashed line represents chemical evolution pathway of a typical evaporitedissolving groundwater (after [19]). Arrows depict possible mixing trends. Seawater is also shown as comparison. 
TABLE 2: Isotopic composition $\left(\delta^{18} \mathrm{O}, \delta^{2} \mathrm{H}\right.$, and $\left.{ }^{3} \mathrm{H}\right)$ and deuterium excess $(d)$ of groundwater and rainwater samples. Sampling for tritium analyses was performed, $06 / 02 / 2018(*$ is used for monthly weighted values and $* *$ is used for the total amount of rainfall collected from 05/11/2007 to $08 / 01 / 2008)$.

\begin{tabular}{|c|c|c|c|c|c|c|c|c|c|c|c|c|c|c|}
\hline & \multicolumn{3}{|c|}{ Mean } & \multicolumn{3}{|c|}{ Min } & \multicolumn{3}{|c|}{ Max } & \multicolumn{3}{|c|}{$\mathrm{SD}$} & & \multirow{2}{*}{${ }^{3} \mathrm{H}$} \\
\hline & $\delta^{18} \mathrm{O}$ & $\delta^{2} \mathrm{H}$ & $d$ & $\delta^{18} \mathrm{O}$ & $\delta^{2} \mathrm{H}$ & $d$ & $\delta^{18} \mathrm{O}$ & $\delta^{2} \mathrm{H}$ & $d$ & $\delta^{18} \mathrm{O}$ & $\delta^{2} \mathrm{H}$ & $d$ & $n$ & \\
\hline S1 & -7.17 & -44.63 & 12.72 & -7.22 & -45.24 & 12.11 & -7.14 & -44.15 & 13.31 & 0.05 & 0.36 & 0.39 & 8 & \\
\hline P1 & -7.04 & -43.81 & 12.49 & -7.14 & -44.35 & 11.70 & -6.95 & -43.18 & 13.32 & 0.06 & 0.38 & 0.50 & 9 & \\
\hline P2 & -7.01 & -44.11 & 11.94 & -7.04 & -44.82 & 11.2 & -6.98 & -43.70 & 12.62 & 0.02 & 0.35 & 0.40 & 9 & \\
\hline P3 & -6.96 & -43.40 & 12.24 & -7.00 & -44.64 & 11.07 & -6.91 & -41.00 & 14.52 & 0.03 & 1.02 & 0.96 & 9 & \\
\hline P6 & -7.04 & -43.12 & 13.23 & -7.24 & -43.50 & 12.45 & -6.98 & -42.80 & 15.12 & 0.08 & 0.24 & 0.84 & 8 & $0.9 \pm 0.4$ \\
\hline P7 & -6.86 & -41.84 & 13.00 & -6.91 & -42.40 & 11.88 & -6.73 & -40.40 & 14.80 & 0.06 & 0.62 & 0.83 & 9 & $2.9 \pm 0,6$ \\
\hline P8 & -6.50 & -41.43 & 10.59 & -6.61 & -42.53 & 9.42 & -6.47 & -40.27 & 12.64 & 0.05 & 0.78 & 1.00 & 9 & \\
\hline P18 & -6.48 & -41.09 & 10.76 & -6.51 & -41.82 & 10.07 & -6.44 & -36.80 & 13.40 & 0.02 & 1.04 & 1.11 & 9 & $5.8 \pm 0.8$ \\
\hline P27 & -6.86 & -42.44 & 12.47 & -6.94 & -43.67 & 11.46 & -6.70 & -41.40 & 13.80 & 0.09 & 0.63 & 0.76 & 9 & \\
\hline VPS & -6.64 & -38.55 & 14.59 & -6.78 & -40.20 & 14.04 & -6.50 & -36.89 & 15.08 & & & & 2 & $2.3 \pm 0.5$ \\
\hline RW1 & $-7.06^{*}$ & $-44.40^{*}$ & 10.58 & -9.28 & -58.76 & 6.60 & -3.76 & -22.27 & 15.50 & & & & 7 & \\
\hline RW2 & $-7.41^{*}$ & $-45.57^{*}$ & 12.13 & -9.18 & -58.31 & 8.21 & -3.29 & -18.11 & 15.46 & & & & 7 & $5.0 \pm 0.6^{* *}$ \\
\hline
\end{tabular}

TABLE 3: Ground elevation of spring and wells versus mean elevation of the recharge area related to the waters collected at the same sites. The latter is calculated from the $\delta^{18} \mathrm{O}$ vertical gradient experimentally obtained at the test site. All the values are expressed in $\mathrm{m}$ asl.

\begin{tabular}{lcccccccccc}
\hline & S1 & P1 & P2 & P3 & P6 & P7 & P8 & P18 & P27 & VPS \\
\hline Elevation & 489 & 372 & 367 & 367 & 388 & 359 & 363 & 339 & 377 & 349 \\
Calculated mean elevation of the recharge area & 414 & 350 & 337 & 297 & 324 & 260 & 106 & 95 & 274 & 170 \\
\hline
\end{tabular}

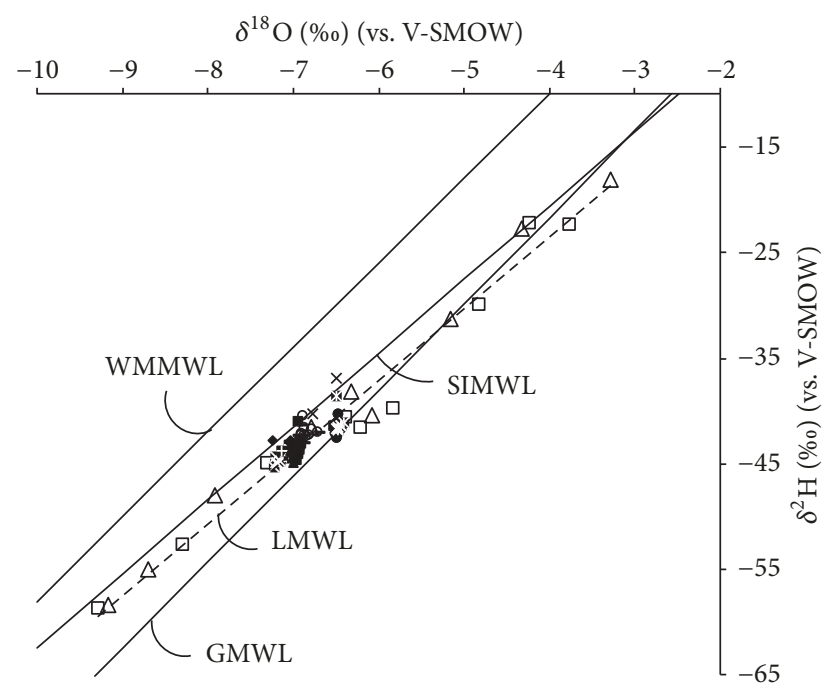

$\begin{array}{llll}\square \text { RWS1 } & \triangle \text { RWS2 } & * \mathrm{~S} 1 & \text { : P1 } \\ \triangle \mathrm{P} 2 & \text {-P3 } & \text { - P6 } & \circ \mathrm{P} 7 \\ \text { - P8 } & \because \mathrm{P} 18 & -\mathrm{P} 27 & \times \mathrm{VPS}\end{array}$

FIGURE 5: $\delta^{18} \mathrm{O}$ versus $\delta^{2} \mathrm{H}$ relationship in mean monthly rainwater samples, collected in RWS1 (square) and RWS1 (triangle), and in spring and groundwater samples. LMWL is the Local Meteoric Water Line $\left(\delta^{2} \mathrm{H}=6.78 \delta^{18} \mathrm{O}+3.65\right)$, and GMLW is the Global Meteoric Water Line [28].

VPS-water (lower subsystem) have ${ }^{3} \mathrm{H}$ content $(2.9 \pm 0.6 \mathrm{TU}$ and $2.3 \pm 0.5 \mathrm{TU}$, resp.) consistent with a prolonged flow of saline and hypersaline $\mathrm{NaCl}$-type water in the aquifer system.

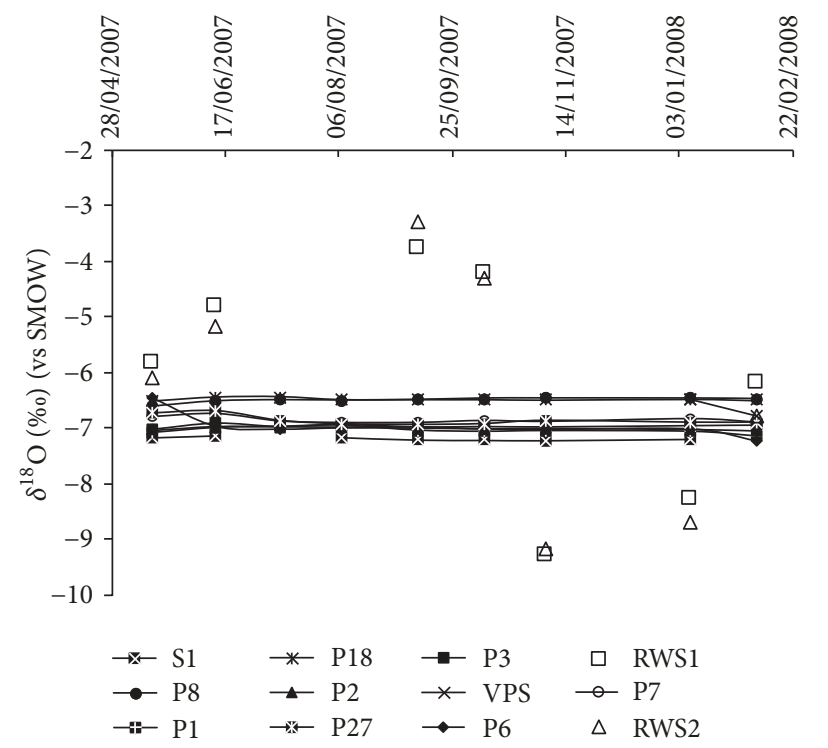

FIgURE 6: Temporal variation of $\delta^{18} \mathrm{O}$ in groundwater samples, compared with the monthly mean $\delta^{18} \mathrm{O}$ in rainwater samples.

The tritium content in hypersaline waters (lower subsystem) is in the range (2.2-3.6 TU) observed by Celico et al. [16] during the hydrologic year 2004/2005 at the same site. P18water (upper subsystem) has a ${ }^{3} \mathrm{H}$ content $(5.8 \pm 0.8 \mathrm{TU})$ close to that detected in local rainwater $(5.0 \pm 0.6 \mathrm{TU})$. Thus, the ${ }^{3} \mathrm{H}$ content in $\mathrm{P} 18$-water is consistent with shorter transit time of freshwater within the upper subsystem. However, as stable isotopes point out, freshwater collected in P18 is 
recharged also by rainwater older than that analyzed during the observed hydrologic year.

As a matter of fact, mixing between older and younger waters influences tritium content of freshwater in the upper subsystem. Concerning brackish and hypersaline waters in the lower subsystem, tritium content could be also influenced by the delay of solute velocity with respect to the velocity of mobile water, caused by diffusive exchange between mobile water in the fissures and stagnant water in the matrix. This is in agreement with findings in other aquifer systems [50]. In fact, according to previous suggestions $[51,52]$, in a doubleporosity medium (such as the studied one [16]), where higher permeability evaporitic layers/lenses coexist with lower permeability argillites, tritium is delayed by diffusion into the microporous matrix by a factor given by the ratio of porosities, and the mean travel time of tritium is related to the mean travel time of water by the porosity retardation factor. Thus, in the case study differences in porosity within the lower subsystem can lead to differences in mean residence time of tritium. This phenomenon could also explain why lower tritium content was detected upgradient $(0.9 \pm 0.4 \mathrm{TU}$ in P6-water), and higher tritium content was detected downgradient $(2.9 \pm 0.6 \mathrm{TU}$ in VPS) within the lower subsystem. Higher mean age in P6-water could be not related to greater flow distances, but to higher porosity retardation factors, and/or lower mixing of older waters with younger ones.

4.4. Microbiological and Biomolecular Analyses. Fresh, brackish, and hypersaline waters were always characterized by microbial pollution of fecal origin (Table 4). In some water samples, fecal enterococci were detected, while fecal coliforms were not. According to previous suggestions [16], this difference should be mainly due to a different halotolerance. In fact, while Escherichia coli (the main species of the fecal coliform group) is a nonhalophilic bacterium [5357], enterococci show a closer phylogenetic relationship to halotolerant species such as Tetragenococcus muriaticus and T. halophila $[58,59]$.

The persistent and widespread microbial contamination of fecal origin clearly suggests that fresh infiltration (polluted) water interacts with groundwater in both the upper and the lower subsystem (therefore suggesting a diffuse hydraulic interaction between the two superimposed subsystems). Variations of bacterial indicator concentrations over time are due to one or more factors, such as (a) timing of manure spreading within the study site, (b) precipitation regime, and (c) soil temperature (freezing and/or freeze-thaw intervals are highly lethal for fecal coliforms and cause temporary inhibition of fecal enterococci before [60, 61]).

At the study area, comparison of the bacterial V3 $16 \mathrm{~S}$ rDNA PCR-DGGE profiles recovered from the observation wells and spring S1 demonstrated significant differences between groundwater samples in terms of bacterial community structures (Figure 7). Cluster analysis revealed the existence of different groups with low level of similarity $(\leq 75 \%$; Figure 7). Moreover, these clusters comprise also wells that differ in terms of location, depth, and water chemistry. These results provide evidence for the absence of an autochthonous bacterial community within the whole system, or within each

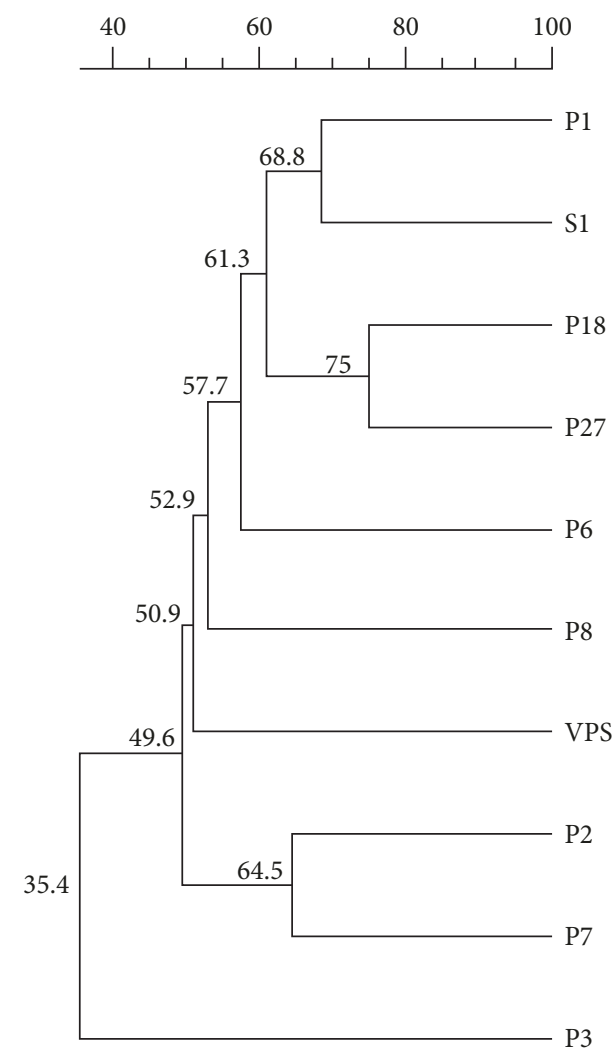

FIGURe 7: Cluster analysis of 16S rDNA PCR-DGGE profiles from the groundwater samples collected at the wells P1, P2, P3, P6, P7, P8, P18, P27, and VPS, and at the spring S1 (dice coefficient with the UPGMA clustering algorithm). Similarity values are shown.

of the two subsystems (upper and lower). Low similarity between deeper wells P2 and P3 (21 m apart) further supports poor interconnection within the lower subsystem at the decametric scale, in agreement with results of the hydrogeological investigations (Section 4.1).

\section{Discussion}

First of all, the purpose-designed interdisciplinary investigations allowed characterizing the complex features as well as the hydrogeological behaviour of the whole heterogeneous low-permeability system. In more detail, this approach allowed us to understand how the pyroclastic horizon (upper subsystem) influences the hydrodynamics and hydrochemistry observed within the evaporate-bearing fine-grained succession (lower subsystem), therefore allowing us to characterize the functioning of the medium of main interest.

Before discussing the behaviour of the evaporate-bearing fine-grained succession, it is then necessary to analyze the whole pyroclastic (upper) and Messinian (lower) system (Figure 8(a)).

The studied system is characterized by vertical and discontinuous heterogeneity (sensu [62]); a sequence of two main superimposed subsystems has been detected (pyroclastic horizon and bedrock), with the deeper one characterized by fractured (karstified) evaporitic intrastrata/lenses. The significant influence of evaporitic beds/lenses on the hydraulic 

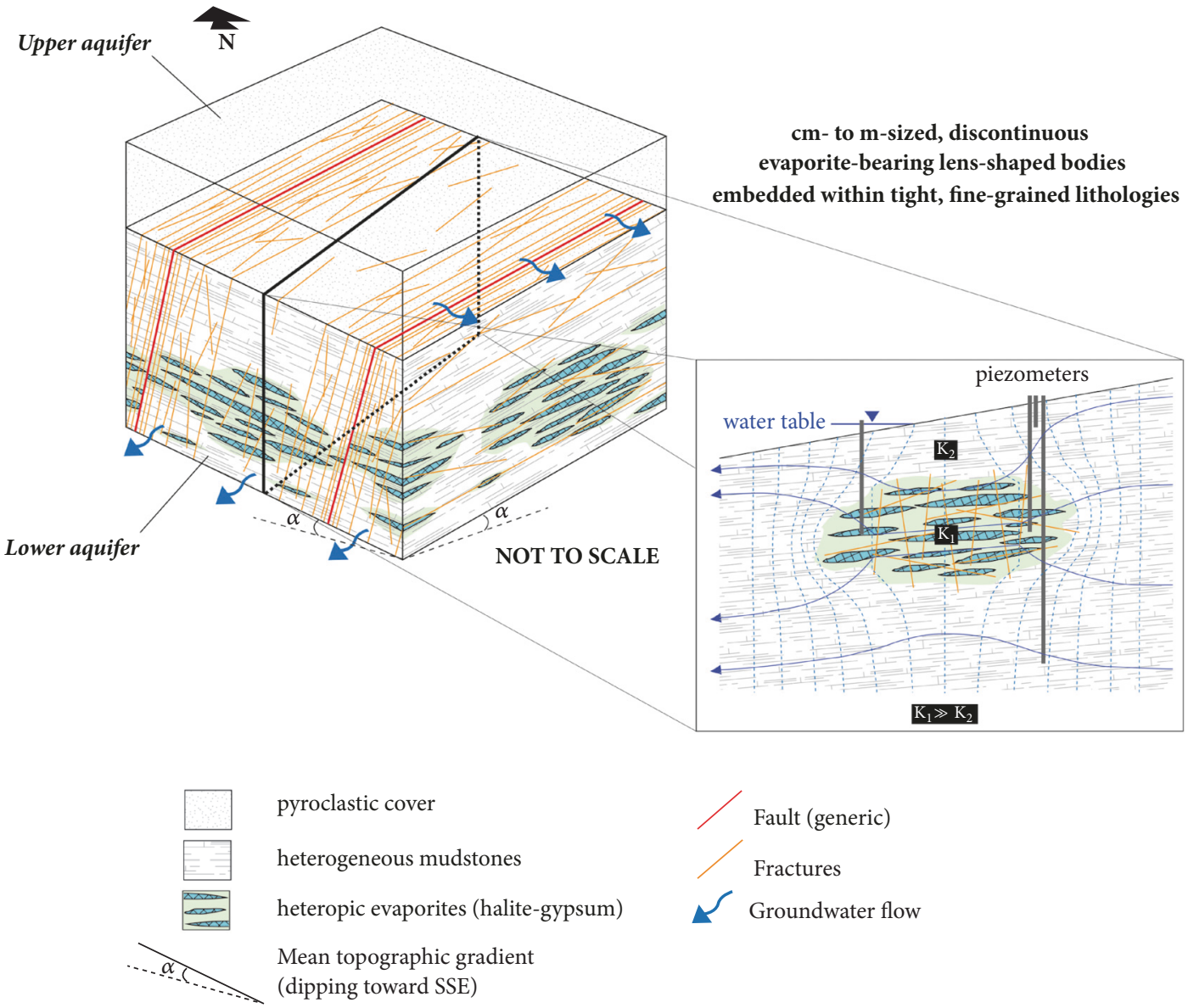

(a)

(m)

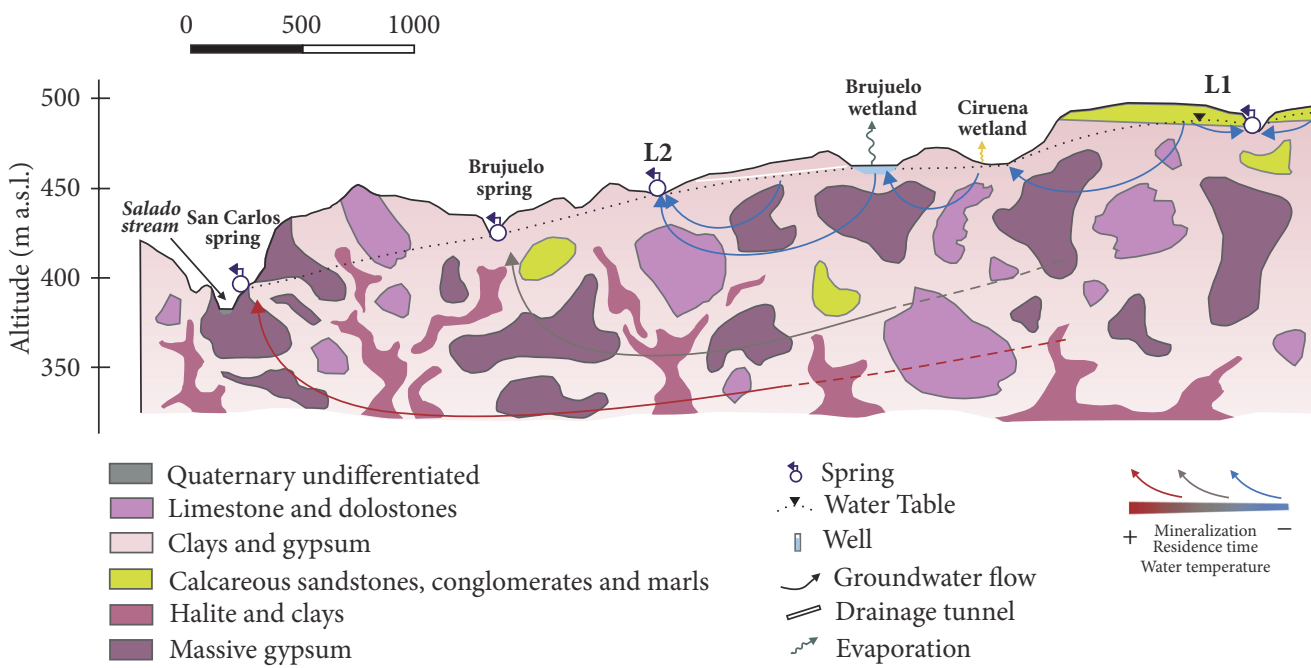

(b)

Figure 8: (a) Conceptual hydrogeological model of heterogeneous media characterized by evaporate-bearing fine-grained succession of Pozzo del Sale and (b) idealized conceptual model of Brujuelo area (modified by Márques et al. 2017). 
TABLE 4: Fecal coliforms (FC) and fecal enterococci (FE) detected in water samples. The values are expressed in CFU/1000 ml.

\begin{tabular}{|c|c|c|c|c|c|c|c|c|c|c|c|c|c|c|c|c|c|c|c|}
\hline \multirow{2}{*}{ Date } & \multicolumn{2}{|c|}{ S1 } & \multirow{2}{*}{$\begin{array}{l}\mathrm{P} 1 \\
\mathrm{FC} \\
\end{array}$} & \multicolumn{2}{|c|}{$\mathrm{P} 2$} & \multicolumn{2}{|c|}{ P3 } & \multicolumn{2}{|c|}{ P6 } & \multicolumn{2}{|c|}{ P7 } & \multicolumn{2}{|c|}{ P8 } & \multicolumn{2}{|c|}{ P18 } & \multicolumn{2}{|c|}{ P27 } & \multicolumn{2}{|c|}{ VPS } \\
\hline & FC & $\mathrm{FE}$ & & $\mathrm{FC}$ & FE & $\mathrm{FC}$ & $\mathrm{FE}$ & FC & FE & $\mathrm{FC}$ & $\mathrm{FE}$ & $\mathrm{FC}$ & $\mathrm{FE}$ & $\mathrm{FC}$ & $\mathrm{FE}$ & $\mathrm{FC}$ & $\mathrm{FE}$ & FC & $\mathrm{FE}$ \\
\hline $03 / 2007$ & 20 & 18 & 12 & & 40 & 20 & 180 & 312 & 492 & 60 & 20 & & & & & & & & \\
\hline $04 / 2007$ & & & 28 & 20 & 8 & 20 & 1712 & 12 & 152 & 300 & 8 & 24 & 40 & 236 & 32 & 48 & 288 & & \\
\hline $05 / 2007$ & 9 & 18 & 408 & 944 & 1520 & 24 & 188 & 720 & 1284 & 52 & 48 & & & 580 & 1080 & 104 & 752 & & \\
\hline $06 / 2007$ & & & 364 & 4000 & 204 & 192 & 540 & 16 & 132 & 152 & 68 & 12 & 2600 & 0 & 308 & 76 & 240 & & \\
\hline 07/2007 & & & 80 & 400 & 92 & 2800 & 2136 & 24 & 1440 & 0 & 24 & 4 & 92 & 0 & 360 & 712 & 492 & & \\
\hline $08 / 2007$ & & & 240 & 696 & 612 & 12 & 272 & 4 & 428 & 16 & 236 & 88 & 4000 & 72 & 120 & 1200 & 180 & & \\
\hline $09 / 2007$ & & & 52 & 36 & 836 & 260 & 760 & 660 & 432 & 0 & 24 & 32 & 108 & 16 & 588 & 2872 & 2456 & & \\
\hline $10 / 2007$ & & & 364 & 1196 & 376 & 172 & 176 & 148 & 448 & 16 & 52 & 4 & 84 & 536 & 1052 & 746 & 272 & & \\
\hline $11 / 2007$ & 4 & 6 & 375 & 456 & & & & 64 & 500 & 24 & 12 & 0 & 88 & 64 & 200 & 252 & 4000 & & \\
\hline $01 / 2008$ & & & 64 & 56 & 252 & 28 & 336 & 560 & 316 & 4 & 4 & 0 & 40 & 84 & 244 & 704 & 596 & 8 & 32 \\
\hline $02 / 2008$ & & & 40 & 68 & 24 & 36 & 112 & 344 & 760 & 0 & 4 & 8 & 140 & 2924 & 1004 & 1360 & 468 & 4 & 8 \\
\hline
\end{tabular}

features of the mainly argillitic bedrock is demonstrated by the relatively high transmissivity calculated through the pumping tests. Intrastratal karstification is due to dissolutional processes of evaporitic layers $[63,64]$.

The whole system can be depicted as a continuous medium, when analyzing the groundwater flow at a scale larger than hectometric, while it behaves as a discontinuous medium when analyzing the hydrodynamics at a smaller scale, with emphasis on the lower subsystem (e.g., Section 4.1). The contrast in permeability with depth and the hydraulic interconnection of the lower subsystem with the outcropping Messinian deposits allow for a significant variation of the hydraulic head with depth. Somewhere, artesian flow has been detected, therefore suggesting the increase of the hydraulic head with depth, and then upflow from the lower subsystem towards the upper one. Conversely, in other parts of the studied aquifer system, the hydraulic head decreases with increasing depth, as demonstrated by the migration of bacteria of fecal origin from the ground surface towards the shallower groundwater and then to the lower subsystem. The detection of huge amounts of fecal bacteria also in P6-artesian-waters suggests that the lower subsystem is fed by the upper one upgradient with reference to the P6.

The complex interaction between upper and lower subsystems, as well as hydrodynamics within the lower one, can be explained assuming minimum or maximum values in head (see details hereafter) localized within the more transmissive, highly fractured evaporite-bearing intervals, which are laterally discontinuous (see also the results of geophysical investigations). In that scenario, the more transmissive and discontinuous localized media drain the surrounding country rock upgradient (lower hydraulic head), while they are characterized by higher head downgradient (somewhere artesian), where they feed the surrounding rock mass (Figure 8(a)).

Complex hydraulic interconnections and permeability distribution within the whole aquifer system, together with the coexistence of different rocks and evaporitic minerals, lead to an extremely articulated hydrochemistry within the saturated zone, and different water types as well as important differences in salinity can be found throughout the studied sequence.
The discontinuous behaviour of the hydraulic system at local scale is further demonstrated by the results of biomolecular investigations that depict a patchwork of poorly connected microcosms and then a sharply fragmented ecosystem where different bacterial communities are confined to defined microhabitats. On the whole, vertical and lateral heterogeneity, together with poor interconnection of fissures in the Messinian deposits at local scale, cause the residence time of water in the subsurface to be really different in different parts of the medium. As a matter of fact, according to the results obtained by Acero et al. [11], the hydrogeology and hydrochemistry of the studied system can be mainly attributed to the mixing of saline groundwater interacting with the evaporitic rocks and the more diluted waters, flowing into an overlying porous aquifer, due to the hydraulic connection between the two subsystems.

In a wider context, the interdisciplinary approach of this study further supported the hypotheses made by Celico et al. [16] and Boschetti et al. [17] from the geochemical (and subordinately microbiological) point of view but went beyond the limits of these essentially monodisciplinary investigations. As a matter of fact, merging old and new chemical and isotopic data with geophysical, hydrogeological, microbiological, and biomolecular data allowed refining knowledge about (i) the 3D hydrogeological model of the test site, (ii) the hydraulic behaviour of each of the coexisting aquifer subsystems and their hydraulic interconnections, and (iii) the main geological and hydrogeological features influencing the variation of chemical and isotopic values over space and time, therefore explaining the geochemical scenario.

\section{Comparison with Other Types of Evaporitic Systems}

When focusing the attention on the only clayey-evaporitic sequence, interesting observations can be made when comparing the conceptual model of Pozzo del Sale with that defined by Gil-Márquez et al. ([15]; Figure 8(b)) in Southern Spain. In fact, in both areas the heterogeneous distribution of evaporites causes the hydraulic conductivity to vary with depth as well as the hydraulic head in the saturated medium. 
This variation causes in both systems the coexistence of down- and upflow in different parts of the shallower medium. At Pozzo del Sale, the local increase in head with depth is demonstrated by artesian wells (Figure 8(a)), while in Southern Spain some springs can be observed along the groundwater pathway (Figure 8(b)).

Despite a similar hydraulic behaviour, the hydrochemistry of the two clayey-evaporitic sequences evolve in a different way. At Pozzo del Sale the layered/discontinuous distribution (interstrata/lenses) of different evaporitic minerals and the poor hydraulic interconnection within the clayey medium at the metric and decametric scales lead to a patchwork of geochemical (and microbiological) subenvironments. On the contrary, results obtained by Gil-Márquez et al. [15] strongly support the hypothesis that most of the studied springs geochemically evolve in a common flow path.

In a wider context, the present study, thanks to the interdisciplinary approach that combines successfully wellestablished investigation methods, allows for refining knowledge about the hydrogeological behaviour of heterogeneous media characterized by evaporate-bearing fine-grained succession. At the same time, it can be used as a sort of guidelines useful to study such complex systems through purposedesigned interdisciplinary approaches.

\section{Conflicts of Interest}

There are no conflicts of interest related to this paper.

\section{Acknowledgments}

The research was funded by the University of Parma (FIL 2015).

\section{References}

[1] R. Selli, "Il Messiniano Mayer-Eymar. Proposta di un neostratotipo (The Messinian Mayer-Eymar. A proposal for a neostratotype)," Giornale di Geologia, vol. 28, pp. 1-33, 1960.

[2] K. J. Hsü, L. Montadert, D. Bernoulli et al., "History of the mediterranean salinity crisis," Nature, vol. 267, no. 5610, pp. 399-403, 1977.

[3] K. J. Hsü, W. B. F. Ryan, and M. B. Cita, "Late miocene desiccation of the mediterranean," Nature, vol. 242, no. 5395, pp. 240244, 1973.

[4] W. Krijgsman, F. J. Hilgen, I. Raffi, F. J. Sierro, and D. S. Wilson, "Chronology, causes and progression of the Messinian salinity crisis," Nature, vol. 400, no. 6745, pp. 652-655, 1999.

[5] L. Vidal, T. Bickert, G. Wefer, and U. Röhl, "Late Miocene stable isotope stratigraphy of SE Atlantic ODP Site 1085: Relation to Messinian events," Marine Geology, vol. 180, no. 1-4, pp. 71-85, 2002.

[6] S. Duggen, K. Hoernie, P. Van den Bogaard, L. Rüpke, and J. P. Morgan, "Deep roots of the Messinian salinity crisis," Nature, vol. 422, no. 6932, pp. 602-606, 2003.

[7] A. Conti, E. Sacchi, M. Chiarle, G. Martinelli, and G. M. Zuppi, "Geochemistry of the formation waters in the Po plain (Northern Italy): An overview," Applied Geochemistry, vol. 15, no. 1, pp. 51-65, 2000.

[8] S. Di Nocera, M. Imperato, F. Matano, D. Stanzione, and GM. Valentino, Caratteri geologici idrogeologici della valle di Ansanto
(Irpinia Centrale, Appennino Campano-Lucano) (Geological and hydrogeological features of the Ansanto Valley (Irpinia, Campano-Lucano Appenine). Boll Soc Geol It, Campano-Lucano Appenine). Boll Soc Geol It. 118, 395-406, 1999.

[9] F. Ortolani, M. de Gennaro, M. Ferreri, MR. Ghiara, D. Stanzione, and F. Zenone, "Prospettive geotermiche dellIrpinia centrale (Appennino Meridionale): studio geologico-strutturale e geochimica (Geothermal perspectives of the central Irpinia (Southern Appenine): geological, structural ande geochemical studies). Boll Soc Geol It," in Prospettive geotermiche dell'Irpinia centrale (Appennino Meridionale): studio geologicostrutturale e geochimica (Geothermal perspectives of the central Irpinia (Southern Appenine): geological, pp. 100-139, structural ande geochemical studies). Boll Soc Geol It. 100, 139-159, 1981.

[10] L. Pingue and G. Marrone, Su alcune acque mineralizzate della provincia di Avellino (Some insight on a mineralized water in the Avellino province), Econ Irp, 5-16, 1972.

[11] P. Acero, L. Auqué, J. Galve et al., "Evaluation of geochemical and hydrogeological processes by geochemical modeling in an area affected by evaporite karstification," Journal of Hydrology, vol. 529, pp. 1874-1889, 2015.

[12] M. Chiesi, J. de Waele, and P. Forti, "Origin and evolution of a salty gypsum/anhydrite karst spring: The case of Poiano (Northern Apennines, Italy)," Hydrogeology Journal, vol. 18, no. 5, pp. 1111-1124, 2010.

[13] C. J. Eastoe, A. Long, and L. P. Knauth, "Stable chlorine isotopes in the Palo Duro Basin, Texas: evidence for preservation of Permian evaporite brines-I. Theory," Geochimica et Cosmochimica Acta, vol. 63, no. 9, pp. 1375-1382, 1999.

[14] B. Andreo, J. M. Gil-Márquez, M. Mudarra, L. Linares, and F. Carrasco, "Hypothesis on the hydrogeological context of wetland areas and springs related to evaporitic karst aquifers (Málaga, Córdoba and Jaén provinces, Southern Spain)," Environmental Earth Sciences, vol. 75, no. 9, article no. 759, 2016.

[15] J. M. Gil-Márquez, J. A. Barberá, B. Andreo, and M. Mudarra, "Hydrological and geochemical processes constraining groundwater salinity in wetland areas related to evaporitic (karst) systems. A case study from Southern Spain," Journal of Hydrology, vol. 544, pp. 538-554, 2017.

[16] F. Celico, P. Capuano, V. De Felice, and G. Naclerio, "Hypersaline groundwater genesis assessment through a multidisciplinary approach: The case of Pozzo del Sale Spring (southern Italy)," Hydrogeology Journal, vol. 16, no. 7, pp. 1441-1451, 2008.

[17] T. Boschetti, V. De Felice, and F. Celico, "The Pozzo del Sale Groundwaters (Irpinia, Southern Apennines, Italy): Origin and Mechanisms of Salinization," Aquatic Geochemistry, vol. 19, no. 4, pp. 303-322, 2013.

[18] T. Boschetti, L. Toscani, O. Shouakar-Stash et al., "Salt Waters of the Northern Apennine Foredeep Basin (Italy): Origin and Evolution," Aquatic Geochemistry, vol. 17, no. 1, pp. 71-108, 2011.

[19] B. B. Hanshaw and W. Back, "Major geochemical processes in the evolution of carbonate-Aquifer systems," Journal of Hydrology, vol. 43, no. 1-4, pp. 287-312, 1979.

[20] A. Crostella and L. Vezzani, "La geologia dellAppennino foggiano," Boll. Soc. Geol. It, pp. 83-121, 1964.

[21] S. Di Nocera and M. Torre, Geologia dellarea compresa tra Delicato e Scampitella (App. foggiano) (Geology of the area between Delicato and Scampitella (Foggia)). Boll Soc Geol It, Geologia dell'area compresa tra Delicato e Scampitella (App. foggiano) (Geology of the area between Delicato and Scampitella (Foggia)). Boll Soc Geol It. 106, 351-364, 1987. 
[22] L. Dazzaro, A. Iannone, M. Moresi, L. Rapisardi, and M. Romeo, "Stratigrafia, sedimentologia e geochimica delle successioni messiniane dellIrpinia al confine con la Puglia (Stratigrafy," sedimentology and geochemistry of Messinian deposits of Irpinia area: Puglia region) Mem Soc Geol It, pp. 41-841, 1988.

[23] C. Basso, S. Di Nocera, F. Matano, and M. Torre, Boll Soc Geol It, Successioni sedimentarie del Messiniano superiore e del Pliocene inferiore-medio in Irpinia settentrionale (Sedimentary succession from Messinian to Pliocene in the northern Irpinia). Boll Soc Geol It. 11, 701-715, 1996.

[24] M. G. De Castro Coppa, M. Moncharmont Zei, T. Pescatore, I. Sgrosso, and M. Torre, "Depositi miocenici e pliocenici ad est del Partenio e del Taburno (Campania) (Miocene and Pliocene deposits eastern to Partenio and Taburno mountain," Tipolito Zuccarello, 1969.

[25] S. Di Nocera, F. Ortolani, M. Torre, and B. Russo, "Evoluzione sedimentaria e cenni di paleogeografia del Tortoniano-Messiniano dellIrpinia occidentale (Sedimentary evolution and paleogeography of Tortoniano-Messiniano age: Western Irpinia," Boll Soc Nat Nap, pp. 90-131, 1981.

[26] Sgrosso I (1971) Note illustrative della Carta Geologica d'Italia alla scala 1:100.000, Fogli 185 (Salerno) 197 (Amalfi) (Illustrative notes of the Geological Map of Italy, 1:100.000 scale, Sheets 185 (Salerno) 197(Amalfi)). Serv Geol It., Roma, Italy, 38 pp.

[27] Di Nocera S, Matano F (2011) Le unità litostratigrafiche messiniane evaporitiche e post- evaporitiche nei Fogli CARG dell'Appennino Campano (Litostatigrafic unit of Messinian evaporites and post-evaporites in the CARG Sheet of the Campanian Appenine). Rend online Soc Geol It. 12:49-53.

[28] L. L. Gourcy, M. Groening, and P. K. Aggarwal, "Stable oxygen and hydrogen isotopes in precipitation," in The Water Cycle: Past, Present and Future of Developing Science, P. K. Aggarwal, J. R. Gat, and K. F. O. Froehlich, Eds., pp. 39-51, Springer, Dordrecht, the Netherlands, 2005.

[29] ISPRA (2016) Carta Geologica d'Italia in scala 1:50.000. Foglio 449 Avellino. (Geological map of Italy, 1:50.000 scale. Sheet 449 Avellino). http://www.isprambiente.gov.it/Media/carg/449_ AVELLINO/Foglio.html.

[30] E. Cardarelli and F. Fischanger, "2D data modelling by electrical resistivity tomography for complex subsurface geology," Geophysical Prospecting, vol. 54, no. 2, pp. 121-133, 2006.

[31] W. Dansgaard, "The O18-abundance in fresh water," Geochimica et Cosmochimica Acta, vol. 6, no. 5-6, pp. 241-260, 1954.

[32] C. Kendall and J. J. McDonnell, "Isotope tracers in catchment hydrology," Isotope tracers in catchment hydrology, 1998.

[33] P. K. Aggarwal, J. R. Gat, and K. F. O. Froehlich, "Isotopes in the water cycle: Past, present and future of a developing science," Isotopes in the Water Cycle: Past, Present and Future of a Developing Science, pp. 1-381, 2005.

[34] I. Clark and P. Fritz, Environmental Isotopes in Hydrogeology, Lewis Publishers, 1997.

[35] N. B. Hanes and R. Fragala, "Effect of seawater concentration on survival of indicator bacteria.," Journal of the Water Pollution Control Federation, vol. 39, no. 1, pp. 97-104, 1967.

[36] G. A. McFeters, G. K. Bissonnette, J. J. Jezeski, C. A. Thomson, and D. G. Stuart, "Comparative survival of indicator bacteria and enteric pathogens in well water," Journal of Applied Microbiology, vol. 27, no. 5, pp. 823-829, 1974.

[37] B. H. Keswick, S. L. Secor, C. P. Gerba, and I. Cech, "Survival of enteric viruses and indicator bacteria in groundwater," Journal of Environmental Science and Health. Part A: Environmental Science and Engineering, vol. 17, no. 6, pp. 903-912, 1982.
[38] G. Bitton, S. R. Farrah, R. H. Ruskin, J. Butner, and Y. J. Chou, "Survival of Pathogenic and Indicator Organisms in Ground Water," Groundwater, vol. 21, no. 4, pp. 405-410, 1983.

[39] A. Pekdeger and G. Matthess, "Factors of bacteria and virus transport in groundwater," Environmental Geology, vol. 5, no. 2, pp. $49-52,1983$.

[40] F. Gich, K. Schubert, A. Bruns, H. Hoffelner, and J. Overmann, "Specific detection, isolation, and characterization of selected, previously uncultured members of the freshwater bacterioplankton community," Applied and Environmental Microbiology, vol. 71, no. 10, pp. 5908-5919, 2005.

[41] D. J. Lane, "16S/23S rRNA sequencing," in Nucleic acid techniques in bacterial systematics, E. Stackebrandt and M. Goodfellow, Eds., pp. 115-175, ohn Wiley \& Sons Ltd, West Sussex, United Kingdom, 1991.

[42] G. Muyzer, E. C. de Waal, and A. G. Uitterlinden, "Profiling of complex microbial populations by denaturing gradient gel electrophoresis analysis of polymerase chain reaction-amplified genes coding for 16S rRNA," Applied and Environmental Microbiology, vol. 59, no. 3, pp. 695-700, 1993.

[43] A. Longinelli and E. Selmo, "Isotopic composition of precipitation in Italy: A first overall map," Journal of Hydrology, vol. 270, no. 1-2, pp. 75-88, 2003.

[44] M. Paternoster, M. Liotta, and R. Favara, "Stable isotope ratios in meteoric recharge and groundwater at Mt. Vulture volcano, southern Italy," Journal of Hydrology, vol. 348, no. 1-2, pp. 87-97, 2008.

[45] E. Petrella and F. Celico, "Heterogeneous aquitard properties in sedimentary successions in the Apennine chain: Case studies in southern Italy," Hydrological Processes, vol. 23, no. 23, pp. 33653371, 2009.

[46] D. Aquino, E. Petrella, M. Florio, P. Celico, and F. Celico, "Complex hydraulic interactions between compartmentalized carbonate aquifers and heterogeneous siliciclastic successions: A case study in southern Italy," Hydrological Processes, vol. 29, no. 19, pp. 4252-4263, 2015.

[47] S. Hamid, M. Dray, A. Ferhi, J. M. Dorioz, M. Normand, and J. C. Fontes, "Étude des transferts d'eau à l'interieur d'une formation morainique dans le bassin du léman-transferts d'eau dans la zone non saturée," Journal of Hydrology, vol. 109, no. 3-4, pp. 369-385, 1989.

[48] S. Segadelli, P. Vescovi, K. Ogata et al., "A conceptual hydrogeological model of ophiolitic aquifers (serpentinised peridotite): The test example of Mt. Prinzera (Northern Italy)," Hydrological Processes, vol. 31, no. 5, pp. 1058-1073, 2017.

[49] J. C. Vogel and H. Van Urk, "Isotopic composition of groundwater in semi-arid regions of southern Africa," Journal of Hydro$\log y$, vol. 25, no. 1-2, pp. 23-36, 1975.

[50] A. Zuber, S. M. Weise, J. Motyka, K. Osenbrück, and K. Rózański, "Age and flow pattern of groundwater in a Jurassic limestone aquifer and related Tertiary sands derived from combined isotope, noble gas and chemical data, Journal of Hydrology, vol. 286, no. 1-4, pp. 87-112, 2004.

[51] I. Neretnieks, "Age dating of groundwater in fissured rock: Influence of water volume in micropores," Water Resources Research, vol. 17, no. 2, pp. 421-422, 1981.

[52] P. Maloszewski and A. Zuber, "Influence of Matrix Diffusion and Exchange Reactions on Radiocarbon Ages in Fissured Carbonate Aquifers," Water Resources Research, vol. 27, no. 8, pp. 1937-1945, 1991.

[53] T. Bernard, J.-A. Pocard, B. Perround, and D. Le Rudulier, "Variations in the response of salt-stressed Rhizobium strains 
to betaines," Archives of Microbiology, vol. 143, no. 4, pp. 359364, 1986.

[54] L. N. Csonka and A. D. Hanson, "Prokaryotic Osmoregulation: Genetics and Physiology," Annual Review of Microbiology, vol. 45, no. 1, pp. 569-606, 1991.

[55] B. Kempf and E. Bremer, "Uptake and synthesis of compatible solutes as microbial stress responses to high-osmolality environments," Archives of Microbiology, vol. 170, no. 5, pp. 319-330, 1998.

[56] R. Talibart, M. Jebbar, G. Gouesbet et al., "Osmoadaptation in rhizobia: Ectoine-induced salt tolerance," Journal of Bacteriology, vol. 176, no. 17, pp. 5210-5217, 1994.

[57] R. Talibart, M. Jebbar, K. Gouffi et al., “Transient accumulation of glycine betaine and dynamics of endogenous osmolytes in salt-stressed cultures of Sinorhizobium meliloti," Applied and Environmental Microbiology, vol. 63, no. 12, pp. 4657-4663, 1997.

[58] M. Satomi, B. Kimura, M. Mizoi, T. Sato, and T. Fujii, “Tetragenococcus muriaticus sp. nov., a new moderately halophilic lactic acid bacterium isolated from fermented squid liver sauce," International Journal of Systematic Bacteriology, vol. 47, no. 3, pp. 832-836, 1997.

[59] H. Robert, C. Le Marrec, C. Blanco, and M. Jebbar, "Glycine betaine, carnitine, and choline enhance salinity tolerance and prevent the accumulation of sodium to a level inhibiting growth of Tetragenococcus halophila," Applied and Environmental Microbiology, vol. 66, no. 2, pp. 509-517, 2000.

[60] V. Allocca, F. Celico, E. Petrella, G. Marzullo, and G. Naclerio, "The role of land use and environmental factors on microbial pollution of mountainous limestone aquifers," Environmental Geology, vol. 55, no. 2, pp. 277-283, 2008.

[61] A. Bucci, V. Allocca, G. Naclerio et al., "Winter survival of microbial contaminants in soil: An in situ verification," Journal of Environmental Sciences, vol. 27, no. C, pp. 131-138, 2015.

[62] R. A. Freeze and J. A. Cherry, (1979) Groundwater. Englewood Cliff.

[63] M. V. Palmer and A. N. Palmer, "Paleokarst of the United States," in Paleokarst - A Systematic and Regional Review, vol. 1 of Developments in Earth Surface Processes, pp. 337-363, Elsevier, 1989.

[64] A. Klimchouk, P. Forti, and A. Cooper, "Gypsum karst of the world: a brief overview," International Journal of Speleology, vol. 25, no. 3/4, pp. 159-181, 1996. 

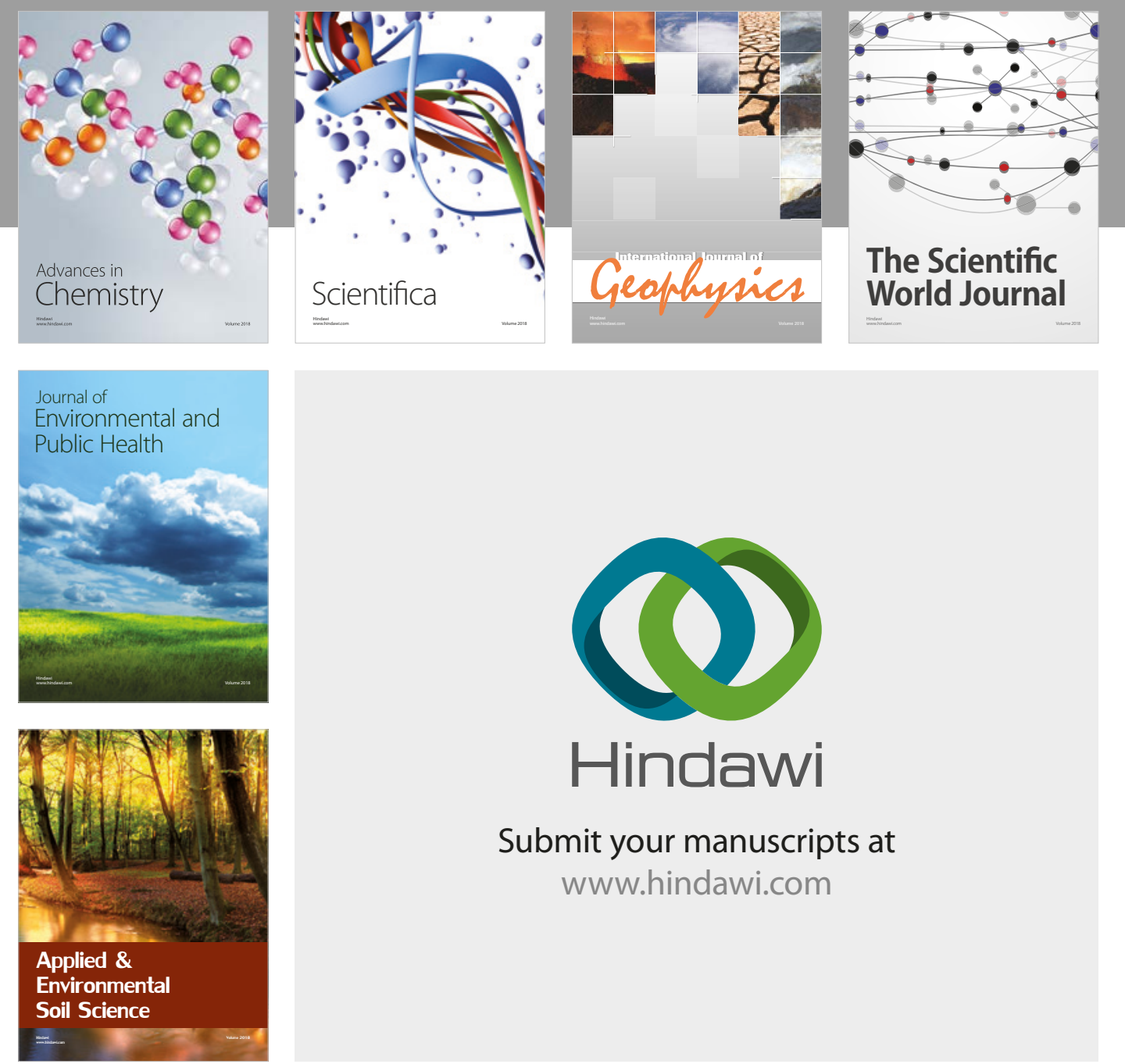

The Scientific

\section{World Journal}
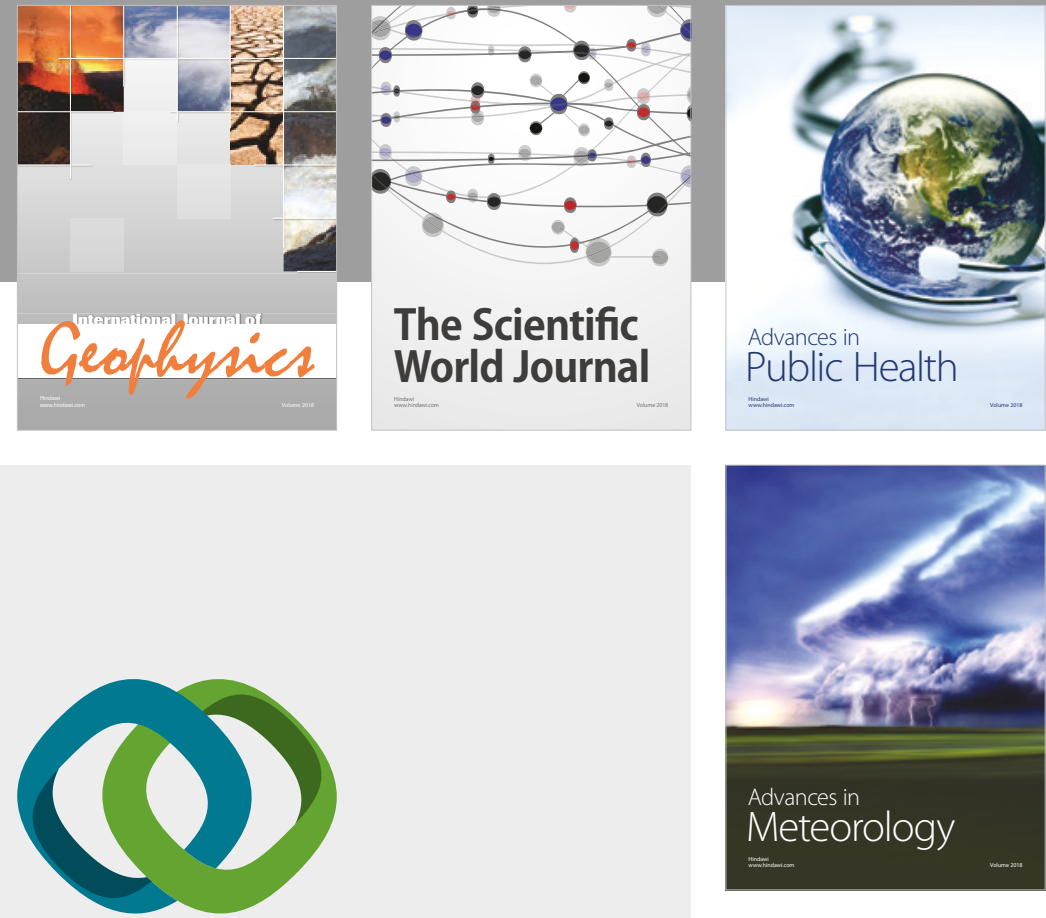

Advan

Public Health

\section{Hindawi}

Submit your manuscripts at

www.hindawi.com
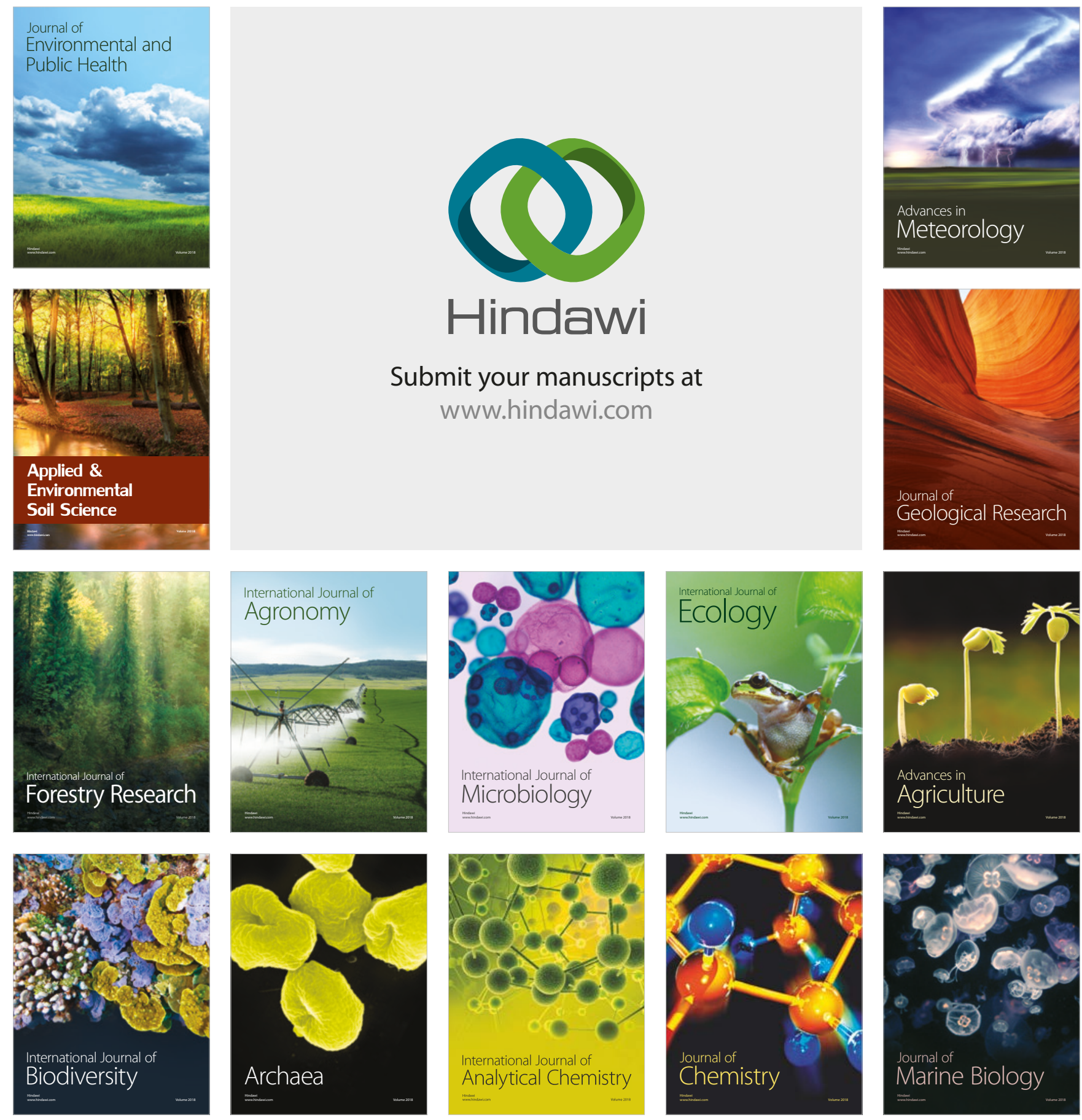